\title{
ECONOMICS
}

\section{CONTRASTING GIANTS: \\ DEMOGRAPHIC CHANGE AND ECONOMIC PERFORMANCE IN CHINA AND INDIA}

by

Jane Golley

The Australian Centre on China in the World Australian National University

and

Rod Tyers

Business School

The University of Western Australia College of Business and Economics

Australian National University

DISCUSSION PAPER 11.04 


\title{
CONTRASTING GIANTS: \\ DEMOGRAPHIC CHANGE AND ECONOMIC PERFORMANCE IN \\ CHINA AND INDIA*
}

\author{
Jane Golley \\ The Australian Centre on China in the World \\ Australian National University \\ Rod Tyers \\ Business School \\ University of Western Australia and \\ College of Business and Economics \\ Australian National University
}

April 2011

Key words:

China, India, demographic change, and economic growth

JEL codes:

C68, E27, F43, J11, O53

\section{DISCUSSION PAPER 11.04}

\begin{abstract}
:
The timing of China's and India's demographic transitions and the implications of alternative fertility scenarios are here explored using a global economic model incorporating full demographic behavior and measures of dependency that include the working aged and those of working age who do not work. The results show that, while the path of total dependency in China will be comparatively flat, the positive contribution of declining youth dependency to real per capita income will not be offset by rising aged dependency until beyond 2030 . India's dependency ratio declines more sharply. Its higher initial fertility contributes positively to growth in GDP while weakening that in its real per capita income. Yet, so long as fertility continues to decline the latter negative effect will be partially offset by a demographic dividend worth at least five per cent of its 2000 real per capita income over more than three decades.
\end{abstract}

* Funding for the research described in this paper is from Australian Research Council Discovery Grant No. DP0557889. Thanks are due to Iain Bain for technical assistance. 


\section{Introduction}

China's exceptional economic growth and development during the last fifty years has been accompanied by equally remarkable demographic change. Rapid drops in mortality and fertility rates ushered in the most rapid "demographic transition" experienced at anytime anywhere in world history. The demographic transition to slower population growth has been profoundly affected by China's family planning policies, culminating in the one-child policy. Yet fertility rates would have declined anyway, affected as they have been in China's Asian neighbours by urbanisation, female education, increases in labour force participation rates, improved life-expectancy of new-born children, high parental costs of a competitive education system and a myriad of other socio-economic factors. Indeed, India's fertility rates have also declined steadily since the 1970s. However, the relatively slow speed of this decline has been among the factors that have delayed India's demographic transition, particularly when contrasted with China's.

There is now plenty of evidence to suggest that the potential "dividend", "gift" or "bonus" associated with the middle phase of the demographic transition, during which dependency ratios fall and the proportion of the working-age population rises, can be quite substantial. Bloom and Williamson (1998) reassess the East Asia "miracle" in this context and, noting the rapid growth of working-age populations across the region between 1965 and 1990, they show that population dynamics could account for as much as one half of the region's growth performance during this period. Cai and Wang (2005) claim that about onequarter of China’s per capita GDP growth during the period 1980-2003 can be attributed to its demographic dividend, which they predict will be exhausted by the year 2015. Similarly, Feng and Mason (2005) argue that the gains from China's dividend (accounting for 15 per cent of growth between 1982 and 2000) have mostly been reaped, although they do also note the persistence of these gains - amounting to 10 per cent higher per capita output in 2050 compared with 1982. Crucially, the demographic dividend is not an automatic consequence of fertility decline, but instead depends "on many policies, institutions and conditions that determine an economy's capacity to equip its people with human and physical capital and to absorb them into productive employment” (Bloom et al., 2000: 259). For India, with its slower and later demographic transition, much of the potential demographic dividend lies ahead. For both China and India, the timing and duration of their respective dividends are still very much open to question. 
Most of the related empirical research defines demographic dividends as stemming from declines in dependency ratios, which are in turn defined as the proportion of populations that are of working-age (Bloom and Williamson, 1998; Bloom and Canning, 2005a, 2007; Bloom et al., 2002; Bloom, et al., 2000; and Cai and Wang, 2005). Yet, in most countries there are substantial groups of “working age” people who do not work, and there are people older than "working age" who do work. A more precise measure of the dependency ratio is the quotient of the non-working and the working populations, and this may differ substantially from the standard measure. Taking this into account we show that China's demographic dividend since the turn of the century will remain positive, if small, beyond 2030, even though total dependency there will begin to rise before then. Put another way, the contribution of age distribution changes since 2000 to the level of China's real per capita income will remain net positive throughout this period.

This finding does not detract from the fact that China's population is aging, which has rightly become a major policy concern in recent years. The proportion of China's aged (60+) population is expected to almost double from 12 per cent in 2010 to 23 per cent in 2030, so that rises in aged dependency will begin to outstrip falls in youth dependency in this period. In contrast, India's aged population will increase from 7 to just 12 per cent over the same period - overall dependency will continue to be dominated by declines in youth dependency, foreshadowing a more substantial demographic dividend. Not surprisingly, these different population structures have elicited different population policy responses, with China now actively discussing (but not moving to) a "two- child policy" (Xinhuanet, 2005, Reuters, 2010), while India continues to grapple with ways to promote fertility decline (Matthews et al., 2009).

In this paper, the linkages between demographic change and economic growth in China and India are explored using a global economic model in which regional households are disaggregated by age and gender and which incorporates full demographic behavior. This composite model provides a means to examine, quantitatively and at a high level of disaggregation, the interactions between demographic change and economic performance. The results confirm that there are significant potential gains to future real per capita income from India's demographic dividend, whereas for China, these gains are largely in the past. Although higher fertility rates and hence more rapid population growth in China might ultimately ease some of the burden of an aging population and contribute to higher rates of growth in GDP, it will be contradictory to the goal of delivering improvements in real per 
capita income. For India, the benefits of reduced fertility, in terms of real per capita income, are shown to be substantial.

The paper is organized as follows. Sections 2 and 3 discuss the various links between demographic transition and economic growth in the context of China and India. In Section 4 the composite model is described and the baseline scenario for the global economy through to 2030 is presented. An alternative "constant population structure" scenario is then introduced to isolate the demographic dividends to be enjoyed by the two countries in the future. Section 5 presents the simulated results of two alternative fertility scenarios: one in which China's fertility rates are higher than currently projected, and the other in which India's are lower. Conclusions are offered in Section 6.

\section{Fertility decline and demographic transition}

Coale and Hoover's (1958) seminal book provides a detailed depiction of how economic development precipitates a country's demographic transition from high to low mortality and fertility. During the first phase, mortality rates - and particularly those of infants and young children - decline substantially due to the effects of economic development on poverty reduction and improvements in food supply, technology, transport and health. This triggers a decline in birth rates in the middle phase, which is compounded by rising costs of child rearing and also to higher opportunity costs of foregoing work opportunities outside the home. Rises in private consumption, female education and life expectancy, along with the affordability and availability of birth control measures, are among the other factors contributing to fertility decline. During the final phase of the transition, further but less marked fertility declines - as parents shift towards "quality not quantity" of children (Demeny and McNicoll, 2006) - are accompanied by fairly steady or slowly declining mortality rates, the latter occurring especially among the elderly population (Bloom et al., 2000). The pace of the transition will vary from country to country, impacted not only by the speed of economic development - and hence the wide range of reforms and policies that shape that development - but also by cultural factors as well as population and family planning policies.

Figure 1 depicts the crude birth rates and death rates for China and India between 1950 and 2010. China's transition began in the early 1950s, with the death rate falling 
dramatically from 25 (per 1000) in 1950 to 11 in 1965. ${ }^{1}$ Infant mortality improved dramatically during this time, while birth rates remained high until $1965 .{ }^{2}$ This year roughly identifies the beginning of the middle phase of China's transition with the birth rate falling steadily from 37 (per 1000) in 1965 to 22 in 1980, by which time the death rate had fallen to 7.3. During the final phase since 1980, the birth rate continued to fall while the death rates changed only slightly, ranging between 6.6 and 7.5 during the period 1980 to 2010. As the figure shows, from nearly identical birth and death rates in 1950, China recorded a more rapid decline in its death rate followed by a more rapid decline in its birth rate, resulting in a more compressed and earlier transition than India. The slow and steady pace of India's transition makes it more difficult to clearly identify the three phases described above, although they can roughly be identified as 1950-75 (during which time the death rate halved), 1975-2000 (during which time the birth rate fell from 36 to 25) and 2000 onwards.

Coale and Hoover's (1958) most lasting contribution has not been on how economic development precipitates demographic transition, but rather on the subsequent impacts of demographic transition on economic growth. Declining mortality rates concentrated among infants and young children combined with high fertility rates initially create high levels of youth dependency, which impedes economic growth. While high fertility rates have a concurrent negative impact on growth, some two decades later, in the middle phase of transition, the proportion of working-age people in the population rises substantially, giving rise to the potential for a "demographic dividend".

With this analysis, Coale and Hoover essentially joined the Malthusian club of "population pessimists" in asserting that fertility reductions, and hence lower population growth, would be good for economic development (or in other words, that rapid population growth was a bad thing) (Bloom and Williamson, 1998). In contrast, "population optimists" contend that rapid population growth allows countries to benefit from economies of scale and promotes the adoption of institutional and technological innovation (e.g. Boserup, 1965) or, in the case of Mao Zedong, that command planning would eliminate the Malthusian-type problems of rapidly growing populations (Sharping, 2003). And then the "neutralists” argue that there is no relationship between the rate of population growth and economic

\footnotetext{
1 The use of five-yearly data smooths over the “demographic disaster” during Mao's Great Leap Forward, which according to the National Bureau of Statistics (2000), resulted in death rates peaking at 25 in 1960. However, they recovered soon thereafter, and had fallen to 9.5 in 1965.

${ }^{2}$ Infant mortality fell from 195 (per 1000) births in 1950-55 to 121 in 1960-65 (United Nations, 2008). As seen in the figure, the Great Leap Forward had a strong impact on birth rates as well. According to the National Bureau of Statistics (2000), these fell to a low of 18 in 1961 and then peaked at 43 in 1963.
} 
development. While there is some evidence in support of the optimists and neutralists, ${ }^{3}$ the recent surge of econometric evidence stemming from Bloom and Williamson (1998) provides substantial evidence in support of the pessimist stance, and it is this stance that we capture in the modelling framework below.

Figures 2 and 3 illustrate the changing age structure of the Chinese and Indian populations during the period 1950-2030, using United Nations (2008) data for the youth (aged 0-14), working-aged (15-59) and aged (60+) populations. There are numerous points of interest to our analysis here. First, the speed and compression of China's demographic transition relative to India's is quite visible in Figure 2, which shows the rapid decline in China's youth dependency through to 2010 and the commencement of rapid aging since then. This combination implies that China's total dependency ratio (defined here simply as the sum of youth and aged dependency) declined through to 2010 and is increasing thereafter, or equivalently, that the proportion of its working-age population increased through to 2010 and is decreasing thereafter, as shown in Figure 3. In contrast, India's demographic transition is visibly much slower, with its total dependency ratio falling throughout the period 1970-2030. This means that the peak of India's working age-non-working age ratio in 2035 is 25 years behind China's in 2010. This implies that China's demographic dividend should essentially come to an end in 2010, although we argue below that this is not actually the case.

It is clear from the above discussion that many different factors impact on the timing, speed and duration of each country's transition. However, none do so more obviously than fertility. Indeed, Coale and Hoover’s (1958: 335) final sentence presents a clear-cut case for fertility reductions: "At any stage in the foreseeable future of the low-income countries with high fertility, a reduction in fertility would produce important economic advantages. Since these advantages are cumulative, the ultimate benefits of fertility reduction are greater, the sooner it occurs”. It was this line of thinking that invoked the idea of a "population problem" and the need for population control as a means of promoting economic development in many developing countries, including China, India, Pakistan, Taiwan, Thailand, Malaysia, Sri Lanka, Egypt and Chile, all of which implemented a range of family planning policies from the 1950s onwards (Caldwell and Zhao, 2006).

\footnotetext{
${ }^{3}$ For example, the neutralists find support in cross-country regressions of economic growth, which have generally found population growth rates to be insignificant (Kelley and Schmidt, 1996). Lal (2006) finds some support for Boserup's view in the positive relationship between population growth and agricultural growth in the Indian economy and uses this to assert that the "population problem" is no longer a problem in India. This is certainly not the "consensus view" that he claims it to be.
} 
While China's and India's family planning policies have clearly differed in style and impact, both countries have a long history of trying to control their expanding populations. ${ }^{4}$ China's controversial one-child policy has undoubtedly reduced fertility rates beyond what they would otherwise have been. Sharping (2003) controls for numerous other factors that affect population growth - including urbanisation, female education, increases in labour force participation and improved life expectancy, all of which would have contributed to declining fertility in China, regardless of its population policy - and estimates that, in the absence of the state's birth control policies, China's population would have been 1.6 billion instead of the 1.27 billion reported at the end of the $20^{\text {th }}$ century, that is, causing a reduction of some 330 million births. Other demographers have estimated the number of births averted by the one-child policy at around 250 million (Lee and Liang, 2006; Xie, 2000), while the National Family Planning and Population Commission of China puts the figure at 400 million. ${ }^{5}$

In September 2010, China "marked the anniversary of its controversial one-child policy with talk of relaxing rules, at least in some provinces” (Reuters, 2010). Although the official line still remains that China will continue to "coordinate its national family planning policy, stabilizing an appropriately low birth rate and improving the quality of its population”, ${ }^{\prime 6}$ the government is certainly prepared to consider the implications of higher fertility rates, as indicated by research conducted by the Development Research Centre of the State Council of China (2000), which projects China's population under a variety of fertility scenarios including a "two-child policy".

Since the early 1950s, family planning in India has focused on sterilization-based methods, initially directed toward males but with female sterilization later emerging as the predominant method (Matthews et al., 2009, Padmadas et al. 2005). Despite fairly rapid declines in the late 1990s in some southern states, Matthews et al. (2009) show that, overall, India has experienced a slow but steady decline in fertility rates, with some stagnation in recent years. In their analysis they consider the potential impact on population growth if India were to shift away from its focus on sterilization and towards something more akin to China’s “fewer, later, longer” policy (adopted there in the 1970s) as a way of achieving more significant fertility decline in the future. ${ }^{7}$ Their population projections suggest that such a

\footnotetext{
${ }^{4}$ For further details on China's population policies, see Sharping (2003), Zhang and Cao (2006) and Liang and Lee (2006), among an extensive list. Matthews et al. (2009) provide excellent details of India's population policies, while Padmadas et al. (2005) covers both countries. See Tyers, Golley and Bain (2009) for a brief summary.

${ }^{5}$ See http://www.npc.gov.cn/pc/11_4/2011-03/10/content_1640532.htm, downloaded on 4 April, 2011.

${ }^{6}$ Chinese Vice Premier Li Keqiang, cited in the The China Daily (2010a).

7 "Later, longer, fewer" refers to later marriage, longer gaps between children and fewer births in total.
} 
policy could reduce India's population by 52 million in 2050 compared with the current fertility trajectory.

As China enters a period of rapid aging and contemplates relaxing its one-child policy even further, and India continues to seek more effective fertility-reduction policies, it is worth considering the impact such policy choices will have on each country's population structure and hence economic performance. According to Padmadas et al. (2005), fertility rates are the main driving force of population change (in absolute terms) in both China and India, but also the most uncertain. ${ }^{8}$ The uncertain link between policies and outcomes is just one of the reasons why fertility projections vary widely. The "high fertility" variant of the United Nations (2008) population projections, for example, implies that India's total fertility rate will fall to 2.46 in 2025-2030, while according to Dyson’s (2002) "low fertility” variant it will reach 1.59 by that time. Regardless of which of these projections turn out to be correct, the key point is this: demographic transitions are not deterministic, but are instead shaped by a range of factors that impact on population structure, of which fertility rates are just one.

\section{Demographic transition and economic growth}

While population projections are certainly complex, the resulting economic impact of the demographic transition is even more so. The standard Solow-Swan model of growth is essentially a population pessimistic one, with the assumptions of diminishing factor returns and constant labor participation rates across an ageless population ensuring that slower population growth reduces GDP growth, but increases per capita income growth. ${ }^{9}$ In reality, as seen above, in a developing country with large number of dependent children, a fall in fertility not only slows population growth, it also reduces the total dependency ratio and raises the proportion of the working-aged population. This effectively boosts the basic Solow-Swan impact on income per capita, giving rise to the demographic dividend. ${ }^{10}$

In addition to these supply-side effects of demographic change on growth, changes in age distributions also have demand-side implications. Lower fertility raises the average age of the population, changing the scale and product composition of final consumption to more strongly reflect the preferences of adults and the aged. More importantly, the associated rise in the proportion of the working-aged population tends to raise the share of households'

\footnotetext{
${ }^{8}$ See also Sharping (2006) and Tyers, Golley and Bain (2009) for further discussion on this point. ${ }^{9}$ See Solow (1956) and Swan (1956), and the detailed analytical review offered by Pitchford (1974: Ch.4).

${ }^{10}$ This can easily be seen by the simple decomposition of per capita income (Y/N) into per worker income (Y/W) times the working-age proportion of the total population $(\mathrm{W} / \mathrm{N})$, where $\mathrm{Y}$ is total income, $\mathrm{N}$ is total population, and W is the working-age population. See Bloom and Canning (2005a) for a clear exposition.
} 
disposable incomes devoted to saving. In a developing country, following a fertility decline, this tends to increase the average savings rate. If investment is also raised, the demographic dividend is further bolstered. ${ }^{11}$ The more open is the capital account the more investment and capital growth depends on the economy's comparative performance and not, narrowly, on its savings behavior. Thus, as China and India trend toward more open capital accounts, the effects of aging via their saving rates are likely to diminish. Indeed, in affecting growth performance, the supply-side effects of demographic change, acting as they do directly through the size of the labor force, tend to dominate demand-side changes in average savings rates and in the product composition of consumption. ${ }^{12}$

Additional complexities include the link between labor force growth, capital returns, and foreign investment. While attracting investment from abroad boosts GDP growth, the new capital returns are repatriated and the contribution to per capita income growth then depends on real wage changes. Faster labor force growth necessarily slows real wage growth even while it attracts foreign investment. The pattern of migration is also dependent on the growth path of real wages. Both China and India are substantial suppliers of (mainly skilled) migrants to the rest of the world. Growth due to boosted fertility, and its slower real wage growth path, would raise skilled emigration and reduce skill endowments in both. Finally, any labor supply-driven acceleration of GDP growth tends to shift the terms of trade adversely by raising output relative to consumption and exports relative to imports (or, equivalently, lower wage costs relative to other regions tend to cause real depreciation). This also tends to weigh down the growth of per capita income. The integrated model of demographic change and economic growth presented in the next section activates most of these interactions and it offers scope to experiment with alternative assumptions about each.

As if that wasn't enough, further complexities arise when the interdependence of fertility, longevity, labor force participation, and savings rates are fully accounted for. In one theoretical study, Bloom and Canning (2005b) predict that improvements in health and longevity will result in rising natural retirement ages (increased aged labor force participation) but declining average savings rates, the latter occurring because longer working lives reduce the need to save for retirement in each successive age cohort. Much more complicated is the impact of alternative pension systems on retirement decisions and savings,

\footnotetext{
11 There is a large literature concerning the relationship between demography and savings, including Higgins (1998), Higgins and Williamson (1997), Chamon and Prasad (2008), Kuijs (2006), Modigliani and Cao (2004), Horioka and Wan (2007), Horioka (2010a,b) and Kinugasa and Mason (2005). We acknowledge that we do not do justice to this topic in this paper.

${ }^{12}$ See Tyers and Shi (2007) for a demonstration of this point.
} 
since different measures to deal with pension-related budgetary pressures will have profoundly different effects. ${ }^{13}$ Furthermore, there is the potential for declining fertility rates to increase labour force participation, particularly among women, as demonstrated by Bloom et al. (2007) for 97 countries over the period 1960-2000, in which they show that higher female participation rates following fertility decline generate per capita income gains of 21 per cent.

\section{Modeling the Demographic Dividend}

The approach adopted follows Tyers and Shi (2007), in that a complete demographic submodel is integrated within a dynamic numerical model of the global economy. ${ }^{14}$ The baseline scenario represents a "business as usual" projection of global demographic change and economic growth through to 2030. Although policy analysis can be sensitive to the content of this scenario, our focus in subsequent sections is the extent of departures associated with alternative assumptions about demographic change in China and India. Nonetheless, it is instructive to describe the baseline because all scenarios have a common set of assumptions about future trends in key exogenous variables and because some exposition of the baseline makes the construction of departures from it clearer. Moreover, it is convenient to use the model to estimate the size of the demographic dividends that could be enjoyed by both economies during the first three decades of this century.

\section{Demographic change}

Each region represented in the model includes four age groups, two genders, and two skill categories, for a total of 16 population groups in each of 18 regions, two of which are Mainland China and India. The four age groups are the dependent young, adults of fertile and working age, older working adults, and the mostly retired over 60s. The skill subdivision is between households that provide production labor (unskilled) and those that provide professional labor (skilled). ${ }^{15}$ Each age-gender-skill group is a homogeneous subpopulation

\footnotetext{
${ }^{13}$ Heller's (2006) recent review of Asian countries' preparedness for future population aging suggests that both China and India lag behind the more advanced but smaller Asian economies in the development of policy regimes to cover pensions, health insurance, and labor market change.

${ }^{14}$ The economic model is a development of GTAP-Dynamic, the standard version of which has single households in each region and therefore no demographic structure. It, in turn, is a development of its comparative static progenitor, GTAP (Hertel 1997). Its dynamics are described by Ianchovichina and Walmsley (2010).

${ }^{15}$ The subdivision between production and professional labor accords with ILO's occupation-based classification and is consistent with the labor division adopted in the GTAP Database. Mothers in families providing production labor are assumed to produce children who will grow up to also provide production labor,
} 
with group-specific birth and death rates and rates of both immigration and emigration. If the group spans $T$ years, the survival rate to the next age group is the fraction $1 / T$ of its population, after group-specific deaths have been removed and its population has been adjusted for net migration.

The final age group (60+) has duration equal to measured life expectancy at 60 , which varies across genders and regions. So the key demographic parameters are birth rates, sex ratios at birth, age-gender specific death, immigration and emigration rates, and life expectancies at $60 .{ }^{16}$ The birth rates, life expectancy at 60 , and age-specific death rates all trend through time asymptotically, approaching a target at a rate of growth determined by historical observation. Of most interest here are the birth rates, which, along with the corresponding total fertility rates (TFR), are listed in Table 1 for China and India. China's baseline TFR is exogenously projected to fall from 1.91 in 1997 to reach 1.44 by 2030, slightly higher than the United Nation's (2008) “low” fertility projection of 1.35. For India, the base year TFR of 3.47 trends asymptotically to a target of 2.56, slightly higher than the United Nation’s (2008) “high” fertility projection of 2.5 for India.

A further key parameter is the rate at which each region's education and social development institutions transform production worker families into professional worker families. Each year a particular proportion of the population in each production worker agegender group is transferred to professional (skilled) status. These proportions depend on the regions' levels of development, the associated capacities of their education systems, and the relative sizes of the production and professional labor groups. The resulting initial rates of transformation are based on changes during the decade prior to the base year, 1997, in the composition of aggregate regional labor forces as between production and professional workers. They change through time in response to changes in skilled wage premia, skilled shares of labor forces and real per capita income (Tyers and Bain 2006).

\section{Measuring dependency and the demographic dividend}

The definition of a population's total dependency ratio and its components is essential to projections of its demographic dividend. We consider the number of full-time equivalent workers, rather than the working-age population, to be the most appropriate measure of the labor force on which these ratios are based. The total dependency ratio is then the ratio of the

while the children of mothers in professional families are correspondingly assumed to become professional workers

${ }^{16}$ See Tyers and Bain (2006) for further details about the global migration flows in this model. 
number of people not participating in labor markets to the number of full time equivalent workers. We will refer to the inverse of this ratio, the number of full-time equivalent workers relative to the number of people not working, as the dividend ratio. Before formalizing this, however, we need to define dependency more precisely, which requires a detailed definition of the labor force.

To evaluate the number of full-time equivalent workers, we first construct labour force participation rates, $P_{a, g, r}$ by age group, $a$, gender, $g$ and region, $r$, from ILO statistics on the economically-active population. We then investigate the proportion of workers that are part time and the hours they work relative to each regional standard for full-time work. The result is the number of full-time equivalent workers, $F_{a, g, r}$. The full-time equivalent labour force in region $r$ and year $t, \bar{L}_{r}^{t}$, then depends on the corresponding regional populations, $N_{a, g, s, r}^{t}$, which are divided between age and gender groups but also according to the skill level on which families depend, $s$ :

$$
\bar{L}_{r}^{t}=\sum_{a=1539}^{60+} \sum_{g=m}^{f} \sum_{s=s k}^{\text {unsk }} L_{a, g, s, r}^{t} \text { where } L_{a, g, s, r}^{t}=\mu_{a, r}^{t} P_{a, g, r}^{t} F_{a, g, r} N_{a, g, s, r}^{t} .
$$

Here $\mu_{a, r}^{t}$ is a shift parameter reflecting the influence of policy on participation rates. The time superscript on $P_{a, g, r}^{t}$ refers to the extrapolation of observed trends in these parameters. For each age-gender group and region, a target country is identified whose specific participation rates are approached asymptotically. The rate of this approach is determined by the observed rate of change in participation during the late 1990s. Target rates are chosen from countries considered "advanced" in terms of trends in labor force participation. Where female participation rates are rising, Norway provides a commonly chosen target because its female labour force participation rates are higher than for other countries. For each agegender group, full-time equivalency then depends on the fraction of participants working full time, $f_{a, g, r}$, and, for those working part time, the ratio of average part time hours to full time hours for that gender group and region, $r_{g, r}$. For each group, the ratio of full time equivalent workers to total labour force participants is then $F_{a, g, r}=f_{a, g, r}+\left(1-f_{a, g, r}\right) r_{g, r} \cdot{ }^{17}$

For China and India, the trends in labor force participation rates are summarised in Table 2. China's aged labor force participation is assumed to rise slightly to allow for the

\footnotetext{
17 Values for $f_{a, g, r}$ and $r_{g, r}$ are approximated from OECD statistics. No data on part time work in non-OECD member countries is readily available and, for India and China, its incidence is likely to be comparatively low. The detailed numbers used are listed by Chan and Tyers (2006: Tables 11 and 12).
} 
expected shortfall in pension income as more retirees leave private sector employment. India has substantially higher aged participation rates, lacking China's central planning history. The other striking pattern is that India's female labor force participation rates are considerably lower in the main working age group (ages 15-59) than those in China. This reduces India's recorded labor force relative to that of China's (seen further below). ${ }^{18}$

Returning to dependency, we identify three component dependency ratios based on the age-gender groups in the model. The first is the youth dependency ratio, defined as the number of dependent children per full time equivalent worker:

$$
R_{r, t}^{Y}=\frac{\sum_{g=m}^{f} N_{015, g}}{\overline{L_{r}^{t}}}
$$

where $N_{015, g, r}^{t}$ is the number in the 0-15 age group, and $\bar{L}_{r}^{t}$ is the full-time equivalent labor force from (1), above. The second is the aged dependency ratio, in which the numerator comprises only the non-working population over 60 . Note that this can be very different from the more conventional aged dependency ratio depending on aged labor force participation:

$$
R_{r, t}^{A N W}=\frac{\sum_{g=m}^{f}\left(N_{60+, g, r}^{t}-L_{60+, g, r}^{t}\right)}{\overline{L_{r}^{t}}}
$$

The third is the working-aged dependency ratio, in which the numerator comprises the non-working population of working age (15-59):

$$
R_{r, t}^{W N W}=\frac{\sum_{a=1539}^{4059} \sum_{g=m}^{f}\left(N_{a, g, r}^{t}-L_{a, g, r}^{t}\right)}{\bar{L}_{r}^{t}}
$$

The sum of these three dependency ratios indicates the number of non-working people of all ages and genders per full-time equivalent worker, and gives our total dependency ratio. This is then defined as the inverse of the dividend ratio, $D$ :

$$
R_{r, t}^{T}=\frac{\sum_{g=m}^{f} N_{015, g, r}^{t}+\sum_{a=1539}^{60+} \sum_{g=m}^{f}\left(N_{a, g, r}^{t}-L_{a, g, r}^{t}\right)}{\bar{L}_{r}^{t}}=\frac{1}{D_{r, t}}
$$

\footnotetext{
${ }^{18}$ Populations and labor forces are disaggregated by skill in the modeling. These splits have little impact on dependency in general and so are averaged out in the table.
} 
Projections of these dependency and dividend ratios are listed in Table 3. Notably, one of the largest dependent groups comprises those of working age who are not participating in the labor market. This is due, in part, to education participation by those over 15, in part to disablement and in part to home-making partners. The simulated changes to 2030 show the expected declines in youth dependency as fertility declines, with a more dramatic drop for India. The associated aging boosts aged dependency, with the non-working aged dependency ratio close to doubling in both countries, albeit from a lower base in India. Declines in youth dependency more than offset rises in aged dependency in both regions but the difference is larger for India. Inverting the total dependency ratios yields dividend ratios that are higher for China (more workers per dependent) but rising much faster for India.

This raises one of the key points of this paper. According to the commonly used measures of dependency (based on United Nation's projections of age structures), China's total dependency ratio is predicted to increase, i.e., its dividend ratio to decline, beyond 2010, as shown in Figure 3. And yet, when the true number of "dependents" is taken into account, as in Table 3, we see that in fact China's dependency ratio is actually lower (and its dividend ratio is higher) in 2030 than it was in 2000. Rising aged dependency is thus projected to take considerable time to overtake the effects of declining youth dependency and this process is projected to be incomplete by 2030 .

\section{Economic growth}

The model of the global economy that embodies the demographic behavior discussed previously considers each region to contribute seven industries: agriculture, light manufacturing, heavy manufacturing, metals, energy, minerals and services. To reflect compositional differences between regions, these products are differentiated by region of origin, meaning that the "light manufactures" produced in one region are not the same as those produced in others. Consumers substitute imperfectly between manufactures from different regions.

To capture the full effects of demographic change, the multiple age, gender, and skill groups are modeled as separate households. These 16 groups differ in their shares of regional disposable incomes, consumption preferences, savings rates, and their labor supply behavior. While the consumption-savings choice differs for each age-gender group, it is dependent for 
all on current group-specific real per capita disposable income and the real lending rate. Governments balance their budgets while private groups save or borrow. ${ }^{19}$

As in other dynamic models of the global economy, the main endogenous driver of simulated economic growth is physical capital accumulation. The transformation of workers from unskilled to skilled is another driving force in this model, with transformation rates differing by age and gender and depending on the real skilled wage premium. In addition, technical change is introduced in the form of exogenous productivity growth that is sector and factor specific. It has the Solow-Swan property, shared with all neoclassical dynamic models that embody diminishing returns to factor use, that an increase in the growth rate of the population raises the growth rate of real GDP but reduces the level of real per capita income (hence reflecting a "population pessimistic" view of the world). What distinguishes the model from its simpler progenitors is the endogeneity of saving rates and its multiregional structure. All regional capital accounts are open and investors have adaptive expectations about real regional net rates of return on installed capital. These drive the distribution of investment across regions. In each, the level of investment is determined by a comparison of net rates of return on domestic installed capital with borrowing rates yielded by a global trust, to which each region's saving contributes, adjusted by calibrated region-specific interest premia.

Consumption-savings preferences are represented by age-gender-skill specific consumption equations that relate real per capita consumption to real per capita income and the real lending rate in each region. There is no endogeneity of saving rates to life expectancy at 60 even though death rates decline through time and life expectancy increases in both nations. ${ }^{20}$ Group saving rates change in response to changes in income and interest rates but, more importantly, regional average saving rates respond to changes in age and skill distributions. As a young population ages, the proportion of its population in the saving age groups rises and so does its average saving rate. In the case of an old population, further aging raises the proportion of non-working aged, and so its average saving rate falls. The Chinese 60+ age group is unusual, at least through the 1990s, in that it has low labor force participation but high state-financed retirement incomes. The pensions, combined with low consumption expenditures due to extended family sharing, lead to high initial retiree saving

\footnotetext{
${ }^{19}$ Unlike the standard GTAP models, in which regional incomes are split between private consumption, government consumption, and total saving via an upper-level Cobb-Douglas utility function that implies fixed regional saving rates, this adaptation first divides regional incomes between government consumption and total private disposable income and then allows endogeneity of group saving rates depending on real disposable income levels and real interest rates.

${ }^{20}$ This endogeneity is suggested by Bloom and Canning (2005b).
} 
rates. Yet because the proportion of the aged retiring on relatively generous state pensions is declining, the $60+$ groups are assumed to have underlying savings rates that fall through time. In the case of India, we have no a priori reason to think that the underlying saving rates will rise or fall, and so these are held constant.

\section{Baseline projections for China and India}

The baseline population and labor force projections for both China and India are illustrated in Figure 4 and the associated changes in the age and gender structure of each are summarized in Table $4 .^{21}$ A dramatic contrast between the projections for China and India is clear from Figure 4. While China's labor force falls short of a 10 per cent increase over the three decades, and declines after 2015, the Indian labor force grows strongly, with expansion continuing beyond 2030. This contrast is primarily due to the relative youth of India's population and its higher initial fertility rate. Even though the two populations are projected to reach rough parity in 2030, the Indian labor force remains smaller, due mainly to lower female participation rates. Accordingly, the projected Indian labor force has proportionally more male workers. Interestingly, the more rapid aging of China's population notwithstanding, the projected labor forces of the two nations maintain very similar proportions of older workers. This is explained by India's comparatively high participation rates of 60+ workers, which are close to double China's for both men and women.

Figure 4 reveals another critical point. The key phase of the demographic dividend can be thought of as the period over which the trend of the labor force exceeds that of the total population, relative to their values in the base year. Despite the fact that China's labor force actually declines beyond 2015, its trend relative to the base year remains above that of the total population. Accordingly, its dependency ratio remains below (and its dividend ratio above) that in the base year. Hence its demographic dividend post 2000, as measured in terms of the resulting increment to per capita real income, might be expected to extend through 2030.

Overall baseline economic performance is suggested by Figure 5. In it we include the performances of the US and Western Europe, to illustrate the relatively strong growth anticipated in China and India and also to show the consequences of our representation of the

\footnotetext{
${ }^{21}$ There are several sets of exogenous baseline shocks the baseline and all other simulations have in common: 1) exogenous technical change, which is specific to primary factors and industries, 2) time-varying risk premia ensure that all new investment is not directed merely to the most populous regions which would otherwise have the highest marginal products of capital, and 3) idiosyncratic shocks to risk premia and investment productivity are introduced to represent the global financial crisis, the principal effects of which are felt in 2008 but the recovery from which in the US and Western Europe is assumed to take five years (Tyers and Bain 2008).
} 
global financial crisis in the baseline projection. In part because of underlying assumptions about continued productivity growth in China, its GDP and its GNP per capita are projected to grow the most rapidly, with India a little behind. China's lead in per capita terms is sustained because of its superior net foreign income in the later years, which stems from its extraordinarily high saving rate and foreign asset accumulation in the interim, and because its population is then contracting while India's continues to expand.

\section{China's and India's demographic dividends, 2000-2030}

In order to isolate the pure effects of changes in age distributions - that is, the demographic dividend - a variant of the model is constructed in which the endogenous demographic behavior is switched off from the year 2000 and the total populations are constrained to grow through time at the same rates as in the baseline projection, so that age distributions are held fixed through time. The resulting simulation therefore picks up the Solow-Swan effects of slowing population growth, which serve to raise real per capita income, but not the effects of changes in age distributions. We take this simulation as a comparator and consider the baseline, with its full demography, as a departure from it in which all shocks and behavior are the same except that age distributions change through time. In one simulation we do this only for China and in the other we do it only for India, in each case regarding the base line with full demography as a departure and recording the differences.

In both cases the aging that occurs after 2000 and through to 2030 raises the proportion of the population engaged in work and so raises real per capita income. As shown in Figure 6, however, the sizes of these demographic dividends are very different. India starts the new millennium with considerably more youth dependency than China and so aging moves this youthful abundance into working age and so reduces overall dependency. The result is a gain of a little over five per cent in real per capita income over the three decades. China, too, has mostly youth dependency but, by 2000, there is much less than in India and so aging is less beneficial, delivering a demographic dividend of about one per cent in real per capita income through to 2030. Indeed, as we see in the section to follow, in the life of this simulation aged dependency rises and, beyond 2030, would become the dominant form of dependency in China.

The fact that China continues to receive a positive demographic dividend through to 2030, albeit a small one, contrasts with recent claims that the end of its demographic transition, and hence its demographic dividend, is imminent. The path for China in Figure 6 indicates that, when we take explicit account in our analysis of the working aged and the non- 
working of working age, per capita income gains due to declines in youth dependency are not wiped out by rises in aged dependency until after 2030, leaving real per capita income larger by a per cent or so in each year than it would have been had no changes in age distribution occurred after 2000.

\section{Alternative Fertility Policies}

To illustrate the impact of different fertility assumptions, we consider two alternative scenarios. The first is for China's fertility rate to be higher than assumed in the baseline, as would presumably be the case if a two-child policy was implemented and responded to. ${ }^{22}$ The second is for India's fertility to decline faster than the baseline assumption. The effect of each is described in turn and, for the economic bottom line, a set of elasticities is constructed that enables the two scenarios to be compared.

\section{A two-child policy for China}

A higher-fertility scenario is constructed that, unlike the baseline, which has declining Chinese fertility, is closer to the State Council's (2000) "two-child policy” and to Sharping's (2000) “delayed two-child policy”. In particular, in China we assume that the total fertility rate for low-skill families rises over the three decades from 1.8. to 2.6 and, for high skill families from 1.3 to 1.8 . The 2030 values compare with 1.6 and 1.2, respectively, in the baseline. This change raises the 2030 population by 19 per cent relative to the baseline. The implications for population and labor force growth are displayed graphically in Figure 7. Critically, the path of China's labor force shifts up by substantially less than that of its population. By 2030, the labor force is larger by 13 per cent and the population by 21 per cent. This is because higher fertility first enlarges the youth population, which does not contribute to the labor force but rather raises dependency. China's population continues to age, however, although more slowly with the higher fertility rate. This can be seen from the non-working-aged dependency ratio in Figure 8. After 2015 there are discernable differences, with the two-child policy yielding a 2030 ratio that is lower by four percentage points than the low-fertility baseline. As the figure shows clearly, however, rising youth dependency dominates declining aged dependency, ensuring that the total dependency rate is higher throughout the period.

\footnotetext{
${ }^{22}$ As noted above, this response is not guaranteed. Zhang (2007), for example, provides evidence of families in rural China shifting from "active resistance against" to "conscious decision for" the one-child limit. However, a recent survey showed that 78 per cent of Chinese people would have two children if allowed (The China Daily (2010b).
} 
The economic effects reflect many, although not all, of the points made in Section 3. In particular, supply-side labor force effects are dominant. The anticipated supply-side story is that the labor force expands, increasing capital productivity, and therefore the return on Chinese investment. This attracts more of the world's savings into China so that its capital stock grows more rapidly. China’s GDP might therefore be expected to be boosted substantially by increased fertility, through its direct and indirect influence over the supply of the two main factors of production, labor and capital. ${ }^{23}$ In per capita terms, however, three forces would conspire to ensure that the average Chinese person bears an economic cost. First, the Solow-Swan predisposition (due to diminishing marginal returns) toward slower real wage growth would tend to slow the growth of income per capita. Second, the associated shift in the age distribution would cause a rise in dependency (or a fall in the dividend ratio, as shown in Figure 9) and hence a further slowing of per capita income growth. Finally, because much of the new capital stems from foreign investment, there is a need to reward its foreign owners resulting in a further loss of national income.

The magnitudes of these changes for key variables are indicated in Table 5. The labor force increase is associated with lower growth paths for both skilled and unskilled wages. ${ }^{24}$ The rate of return on installed capital in China is raised and so, therefore, is the level of investment and the growth in the physical capital stock. Yet because the original stimulus is labor force expansion, this is insufficient to prevent a decline in labor productivity and hence in real wages. The terms of trade deteriorate slightly due to expansion in China's exports and its greater market power on the export than the import side. In the end, China's 2030 GDP is higher by 5.8 per cent compared with the baseline. And the rise in dependency, the slowdown in real wage growth, the repatriation abroad of an increased proportion of the income accruing to capital, the small addition to skilled emigration, and the terms-of-trade deterioration all conspire to slow the rate of growth in real per capita income. By 2030 it is smaller than the baseline by 8.1 per cent. This represents a significant cost of "pushing the fertility button” to achieve higher GDP growth. ${ }^{25}$

\footnotetext{
${ }^{23}$ This result could have a number of economic implications that are not captured in our model, including that higher fertility might reduce pressure on fiscal policy and so the growth-retarding effects of tax distortions might be reduced. Our scenarios maintain constant tax rates and fiscal deficits.

${ }^{24}$ This has some effect on migration, but the effect is too small to give more space here. More details about the migration behavior embodied in the model are provided by Tyers and Bain (2006).

${ }^{25}$ Empirical evidence for such terms-of-trade effects from growth is variable. In many cases, developing country expansions have not caused adverse shifts in their terms of trade because their trade has embraced new products and quality ladders in ways not captured by our model. See the literature on the developing country exports fallacy of composition argument, including Lewis (1952), Grilli and Yang (1988), Martin (1993), Singer (1998), and Mayer (2003).
} 


\section{Lower fertility in India}

The low fertility scenario for India embodies a fall in the total fertility rate to 1.55 by 2030, compared with 2.55 in the baseline simulation, thus reducing fertility by one child per woman. ${ }^{26}$ The simulation is therefore similar to Dyson's (2002) “low fertility” variant. As shown in Figure 7, it offers substantial slowdowns in both the population and the labor force, with both tending to stabilize by around 2030. As in the fertility shock to China, the effect on the labor force is proportionally smaller than that on the population. Again, this is because fertility changes first affect the youth population, and not those of working age. In contrast with China, however, in India the difference is made larger by its young population, its large population of women of fertile age, and its high, aged labor-force participation rates. The diminished slowing impact on the labor force results in a substantial decline in the total dependency ratio (and therefore a substantial rise in the dividend ratio), which is the combination of a minimal rise in non-working-aged dependency combined with a dramatic decline in youth dependency, as shown in Figures 8 and 9.

The economic implications of this are indicated in Table 5. Slower labor force growth yields slower capital productivity growth and therefore slower investment and capital accumulation. With slower primary factor accumulation comes slower GDP growth-real GDP reaches a 2030 level that is 7.9 per cent lower than the baseline. By contrast with China's fertility increase, the forces influencing real per capita income are all positive, which amplifies the Solow-Swan predisposition toward inverse proportionality between the growth rates of population and per capita income. Even though aged dependency rises slightly, overall dependency falls substantially and slower population growth makes the average Indian better off. By 2030, the cost in GDP is 7.9 per cent relative to the baseline but the gain in real per capita income is 15.2 per cent.

\section{Comparing the Implications of Fertility Change in China and India}

Figure 10 reveals that, by 2030, the real per capita income cost to China of increasing its fertility rate is roughly equal to the benefits to aggregate GDP, in percentage terms. In India, by contrast, real per capita income gains come at the expense of much less GDP. To clarify this asymmetry, we extract the elasticities of GDP and per capita income to the target

\footnotetext{
${ }^{26}$ These are averages over the "skilled" and "production worker" populations the shocks to the target levels of fertility in each being proportionally the same and sufficient to yield and average change of one child per woman.
} 
fertility rate - that rate toward which fertility is assumed to trend asymptotically. ${ }^{27}$ This yields unitless measures that are independent of the directions of the fertility shocks. As shown in Figure 11, these elasticities change through time because, following a shock to the target fertility rate, the economic implications enlarge with departures from the baseline population and labor force. While the effects of fertility change on GDP are found to be fairly similar for the two countries, the benefit in per capita terms of reducing fertility in India is more than twice as large is in China. This stems primarily from India's comparatively young population and the more considerable demographic dividend it can therefore derive from fertility decline.

\section{Conclusions}

Within the next decade, China's labor force will begin to contract, while that of India will expand faster than its population. A straightforward consideration of this in a neoclassical model with diminishing factor returns leads to the expectation that the impact of these changes will be lower GDP and higher per capita income growth in China, and the reverse in India, and this general pattern does emerge from the analysis provided above. However, the story is considerably more complex than this. In particular, population structure plays a critical role in determining the relative magnitudes of labor force growth to total population growth and the consequent change in dependency ratios, which in turn impact significantly on per capita income growth. Moreover, real wage trends influence skilled emigration from these regions and therefore the skill composition of their labor forces. With increasingly open capital accounts, other things equal, both countries stand to attract more foreign investment the faster their labor forces grow. This complements the positive association between fertility and GDP but the necessity to compensate foreign capital owners detracts from the per capita income result. Finally, faster GDP growth tends to shift the terms of trade adversely, which also detracts from per capita performance. Our integrated model of global demography and economic growth offers some insight into all of these complexities.

Given their very different population age structures, the differences in timing and magnitude of China's and India's demographic dividends comes as no surprise: China's largely lies in the past while India's lies in the present. However, the use of the working population, rather than the working-age population, to measure dependency reveals that China's dividend (due to age distribution changes from 2000) is projected to be positive

${ }^{27}$ Virtually the same result emerges when the contemporaneous fertility rate is used. 
through 2030. More critically, this "true” dependency ratio reflects the actual benefits from having a rising share of workers in the population, rather than the potential benefits of having a rising share of the merely working aged. Our findings do not refute the empirical stream of work that highlights the significance of the demographic dividend as a key determinant of economic growth. Rather they reinforce it, since age distribution effects are larger, particularly in China's case, when actual participation rates are properly accounted for.

A relaxation of the one-child policy has been proposed by some as a way of combating the negative impact that the slowdown and aging of China's population will have on GDP growth in the future. Our simulations indicate that this would indeed achieve the twin goals of increasing GDP and reducing the proportion of the aged population. They also imply, however, that per capita income by 2030 would be reduced by almost as much as GDP would rise. If higher fertility rates are considered desirable for China to achieve its GDP growth and other (libertarian) objectives, policy efforts will need to be directed toward mitigating the negative impact of higher population growth on per capita income by raising labor market participation rates and increasing retirement ages.

In contrast, India is set to become the world's most populous country by 2030, and its population policy continues to be directed toward promoting fertility decline. While lower fertility reduces GDP and increases per capita income in both countries, India gains substantially more per capita income than China per unit change in fertility, a result that depends critically on India's higher youth dependency. India therefore has considerably more to gain, at least in per capita terms, from further reducing its fertility.

\section{References}

Bloom David E. and David Canning 2005a. "Global Demographic Change: Dimensions and Economic Significance," in Global Demographic Change: Economic Impacts and Policy Challenges, Federal Reserve Bank of Kansas City.

Bloom David E. and David Canning. 2005b. "The effect of improvements in health and longevity on optimal retirement and saving”, NBER Working Paper No.10919, Cambridge, MA: National Bureau of Economic Research, April.

Bloom, David E., David Canning, Günther Fink and Jocelyn Finlay. 2007. "Fertility, female labour force participation and the demographic dividend”, NBER Working Paper 13583.

Bloom, D., D. Canning and J. Sevilla, 2002 The Demographic Dividend: a new perspective on the economic consequences of population change, Santa Monica, CA: RAND, MR-1274 
Bloom, David E., David Canning, Pia N. Malaney (2000), "Population Dynamics and Economic Growth in Asia”, Population and Development Review, Vol. 26 Supplement: Population and Economic Change in East Asia: 257-90.

Bloom, D.E. and J.G. Williamson. 1998. "Demographic transitions and economic miracles in emerging Asia”, World Bank Economic Review 12(3): 419-455.

Boserup, Ester (1965), The Conditions of Agricultural Growth: The economics of agrarian change under population pressure, Aldine, Chicago.

Cai, Fang and Dewen Wang. 2005. 'Demographic Transition: implications for growth' in Garnaut and Song, eds, The China Boom and its Discontents, Asia-Pacific Press, Canberra.

Caldwell, John C. and Zhongwei Zhao (2006) “China’s Demography in Perspective” in Zhao Zhongwei and Fei Guo (eds) Transition and Challenge: China's Population at the Beginning of the $21^{\text {st }}$ Century, Oxford: Oxford University Press.

Chamon, Marcos and Eswar Prasad, 2008. "Why are Saving Rates of Urban Households in China rising?” IMF Working Paper WP/08/145.

Chan, M.M. and R. Tyers. 2006. "Global demographic change and labor force growth: projections to 2020”, Centre for Economic Policy Research Discussion Paper, Research School of Social Sciences (RSSS), Australian National University, December.

Coale, Ansley J. and Edgar M. Hoover (1958) Population Growth and Economic Development in Low-Income Countries: A Case Study of India's Prospects, Princeton University Press, Princeton.

Demeny, Paul and Geoffrey McNicoll (2006), "World Population 1950-2000: Perception and Response" in Demeny, Paul and Geoffrey McNicoll (eds), The Political Economy of Global Population Change 1950-2000, Population and Development Review, Supplement to Volume 32, New York: Population Council.

Development Research Centre of the State Council of China. 2000. China Development Studies: the Selected Research Report of the Development Research Centre of the State Council, China Development Press.

Dyson, T. 2002. "On the future of human fertility in India”, Paper presented at the "Expert Group Meeting on Completing the Fertility Transition”, United Nations Population Division, New York.

Feng, W. and A. Mason. 2005. "Demographic Dividend and Prospects for Economic Development in China”, UN Expert Group Meeting on Social and Economic Implications of Changing Population Age Structures, Mexico City, August 31September 2.

Grilli, E. and M.C. Yang. 1988. "Primary Commodity Prices, Manufactured Goods Prices and the Terms of Trade of Developing Countries: What the Long Run Shows”, World Bank Economic Review, 2(1), January.

Heller, P.S. 2006. “Is Asia prepared for an aging population?”, IMF Working Paper WP/06/272, International Monetary Fund, Washington DC, December.

Hertel, T.W. (editor). 1997. Global Trade Analysis Using the GTAP Model, New York: Cambridge University Press. Available: http://www.agecon.purdue.edu/gtap.

Higgins, Matthew. 1998. “Demography, National Savings and International Capital Flows”, International Economic Review, Vol. 39, No. 2: 343-369, May.

Higgins, M. and J.G. Williamson. 1997. “Age structure dynamics in Asia and dependence on foreign capital” Population and Development Review: 23: 261-93.

Horioka, Charles Y. 2010a. "Aging and saving in Asia”, Pacific Economic Review 15(1): 4655. 
Horioka, Charles Y. 2010b, “The (dis)saving behaviour of the aged in Japan”, Japan and the World Economy 22: 151-58.

Horioka, C.J. and J. Wan. 2007. "The determinants of household saving in China: a dynamic panel analysis of provincial data”, Journal of Money, Credit and Banking, 39(8): 2077-2096.

Kelley, A.C. and R.M. Schmidt. 1996 “Saving, dependency and development” Journal of Population Economics 9:365-86.

Kuijs, L., 2006. “How will China’s saving-investment balance evolve?” World Bank Policy Research Working Paper 3958, Beijing, July.

Ianchovichina, E. and T. Walmsley 2010, Dynamic Modeling and Applications in Global Economic Analysis, forthcoming, Cambridge University Press.

Kinugasa, T. and A. Mason. 2005. "The effects of adult longevity on saving”, mimeo, University of Hawaii at Manoa.

Lal, Deepak (2006) “India: Population Change and Its Consequences” in Demeny, Paul and Geoffrey McNicoll (eds), The Political Economy of Global Population Change 19502000, Population and Development Review, Supplement to Volume 32, New York: Population Council.

Lewis, W.A. 1952. "World Production, Prices and Trade, 1870- 1960”, Manchester School of Economic and Social Sciences, 20(2):105-38, May.

Liang Qiusheng and Che-Fu Lee (2006) "Fertility and population policy: an overview" in Poston, D.L. Jr, Che-Fu Lee, Chiung-Fang Change, Sherry L. McKibben and Carol S. Walther, (eds.) Fertility, Family Planning and Population Control in China, Oxford and New York: Routledge Studies in Asia's Transformations.Liu, J. N. Van Leeuwen, T.T. Vo, R. Tyers, and T.W. Hertel. 1998. “Disaggregating Labor Payments by Skill Level in GTAP”, Technical Paper No.11, Center for Global Trade Analysis, Department of Agricultural Economics, Purdue University, West Lafayette, September.

Mason, Andrew (2005) "Demographic transition and demographic dividends in developed and developing countries”, UN Expert Group Meeting on Social and Economic Implications of Changing Population Age Structures, Mexico City, August 31September 2.

Martin, W. 1993. "The fallacy of composition and developing country exports of manufactures”, The World Economy 23: 979-1003.

Matthews, Zoë, Sabu Padmadas, Inge Hutter, Juliet McEachran and James Brown (2009), "Does early childbearing and a sterilization-focused family planning programme in India fuel population growth?, Demographic Research Volume 20, Article 28: 693720

Mayer, J. 2003. “The fallacy of composition: a review of the literature”, UNCTAD Discussion Paper No. 166, February.

Modigliani, F. and S.L. Cao (2004), "The Chinese saving puzzle and the life-cycle hypothesis”, Journal of Economic Literature, 42(1): 145-170, March.

National Bureau of Statistics (2000), 1949-99 China Statistical Data Compilation, Beijing.

Padmadas, Sabu, Guangzhou Wang, James Brown and Bohua Li. 2005. 'Birth planning and population prospects in China and India', Paper presented at the IUSSP XXV International Population Conference, Tours, France, July 18-23.

Pitchford, J.D. 1974. Population in Economic Growth, Amsterdam: North Holland Publishing Co.

Reuters (2010) “China offers hope of easing one-child policy”, 26 September, downloaded at http://www.reuters.com/article/idUSTRE68P05720100926 on October 10. 
Sharping, T. 2003. Birth Control in China 1949-2000: Population policy and demographic development, Routledge Curzon, London.

Singer, H.W. 1998. "Beyond terms of trade: convergence/divergence and creative destruction”, Zagreb International Review of Economics and Business 1(1): 13-25, May.

Solow, R.M. 1956. “A Contribution to the Theory of Economic Growth”, Quarterly Journal of Economics, 70 (1): 65-94.

Swan, T.W. 1956. "Economic Growth and Capital Accumulation”, Economic Record, 32 (2): 334-61.

The China Daily (2010a) “China will coordinate Family Planning Policy”, downloaded at http://www.chinadaily.com.cn/china/2010-09/22/content_11336504.htm on October 14.

The China Daily (2010b), "Most people want two children, survey says”, downloaded at http://www.npfpc.gov.cn/en/detail.aspx?articleid=100329145536375196 on 20 October 2010.

Tyers, R. and I. Bain. 2006. “The global implications of freer skilled migration”; Working Papers in Economics and Econometrics No. 468, Australian National University, Canberra, July, revised September 2007.

Tyers, R. and I. Bain. 2008. “American and European financial shocks: implications for China's economic performance”, Chapter 4 in Song. L. and W.T. Woo (eds.), China's Dilemma: Economic Growth, the Environment and Climate Change, Asia Pacific Press, the Brookings Institution Press, and Social Sciences Academic Press, Beijing, July 2008, pp 59-89.

Tyers, R. and J. Golley (2010), “China’s Growth to 2030: The Roles of Demographic Change and Financial Reform”, Review of Development Economics. 14(3): 592-610. Earlier version in Chinese: China Labour Economics, 4(1): 6-30, 2007.

Tyers, R., J. Golley, Y. Bu and I. Bain (2008), “China’s economic growth and its real exchange rate”, China Economic Journal, 1(2): 123 - 145, July.

Tyers, R. and Q. Shi. 2007. "Global demographic change, policy responses and their economic implications”; The World Economy 30(4), April 2007.

United Nations. 2000. “1997 United Nations Demographic Yearbook” UN Department of Economic and Social Affairs, New York.

United Nations. 2003. World Population Prospects: The 2002 Revision, UN Population Division, February. Available: www.un.org/esa/population/publications/wpp2002.

United Nations. 2005. World Population Prospects: The 2005 Revision, UN Population Division.

United Nations. 2008. World Population Prospects: The 2008 Revision, UN Population Division. Available: http://esa.un.org/unpp/

Xinhuanet. 2005. 'Family planning becomes controversial topic', 30 December

Zhang, Hong (2007), "From resisting to "embracing”? the new One-Child Rule: understanding new fertility trends in a central China village”, The China Quarterly 192: 855-75

Zhang, Weiguo and Xingshan Cao (2006) "Family Planning During Economic Reform Era” in Zhao Zhongwei and Fei Guo (eds) Transition and Challenge: China's Population at the Beginning of the $21^{\text {st }}$ Century, Oxford: Oxford University Press. 
Figure 1: Crude birth and death rates, China and India, 1950-2010

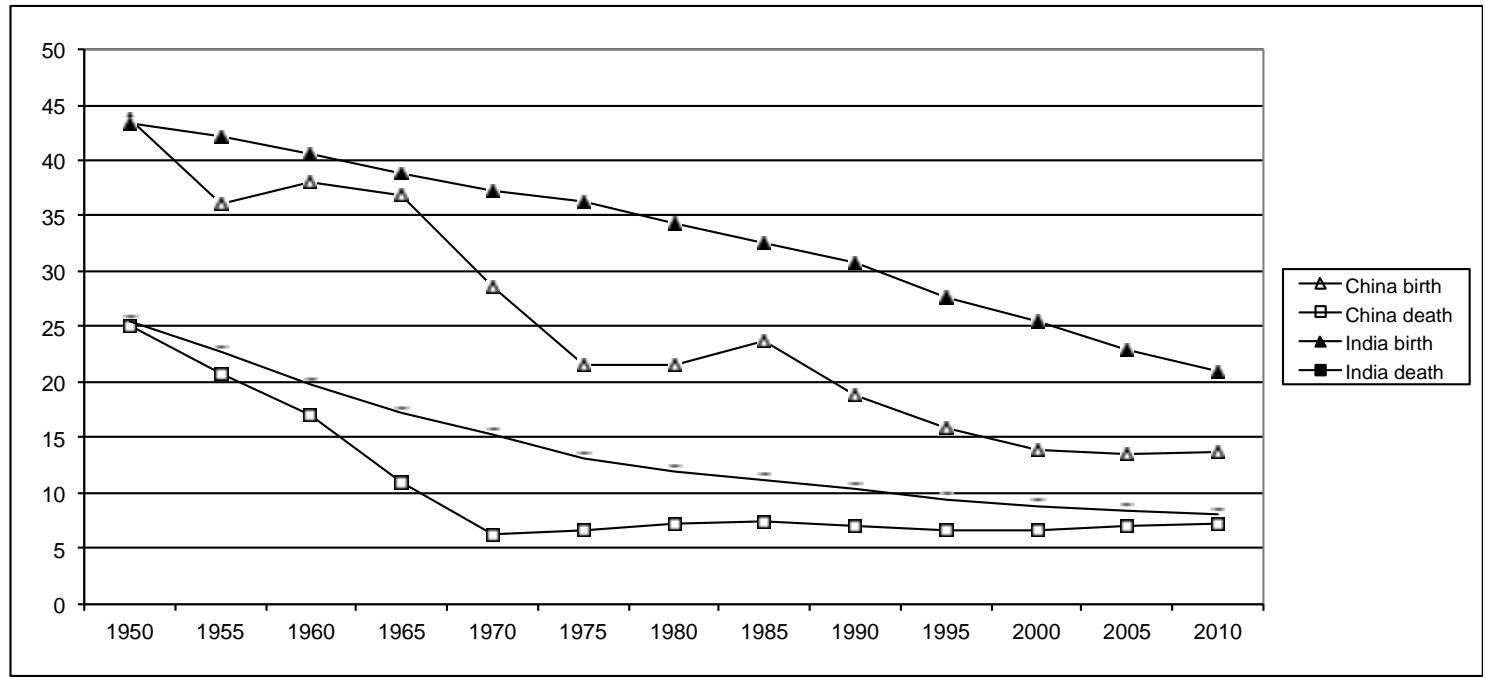

Source: United Nations (2008). Crude birth and death rates are number of births and deaths over a given period divided by the person-years lived by the population over that period. They are expressed as number of birth/deaths per 1000 population.

Figure 2: Youth and aged to working-aged population ratios, China and India, 19502030

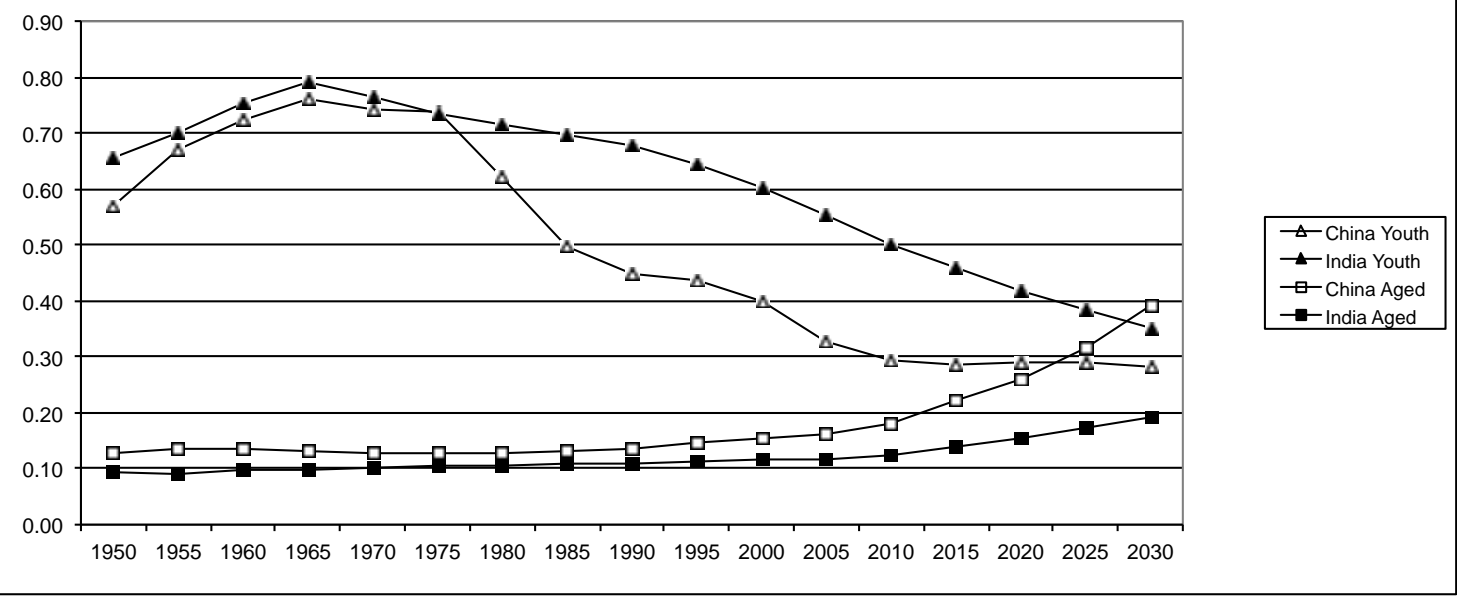

Source: United Nations (2008), populations projections based on medium fertility variant. Youth dependency ratio is number of youth (0-14 years) divided number of working-aged (15-59 years) in the total population. Aged dependency is number of aged $(60+)$ divided number of working-aged (15-59 years) in the total population. 
Figure 3: Working-age to non-working aged ratio, China and India, 1950-2030

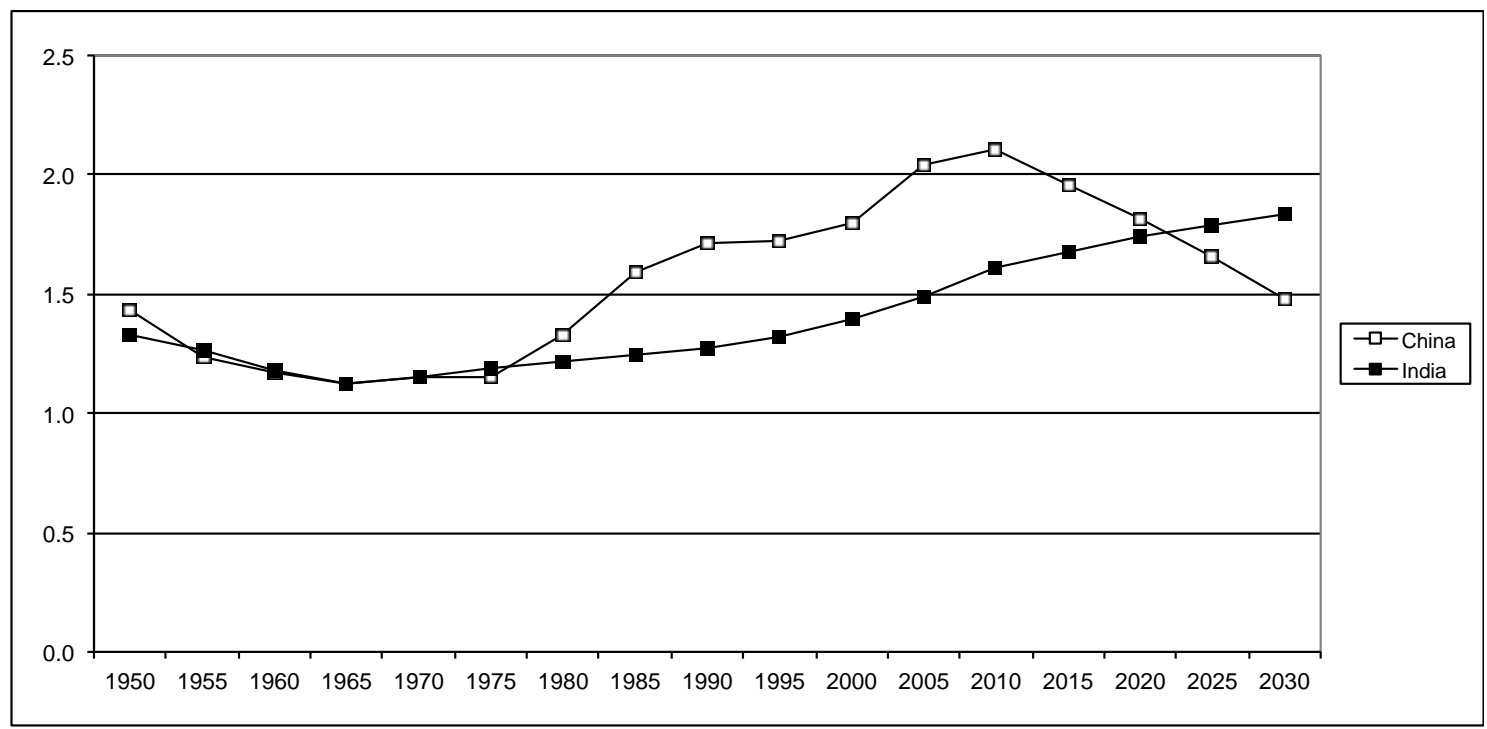

Source: United Nations (2008), populations projections based on medium fertility variant. Ratio is the workingage (15-59 years) population divided by the non-working age (0-14 years and 60+ years).

Figure 4: Projected Populations and Labor Forces, People's Republic of China and India $^{\mathbf{a}}$

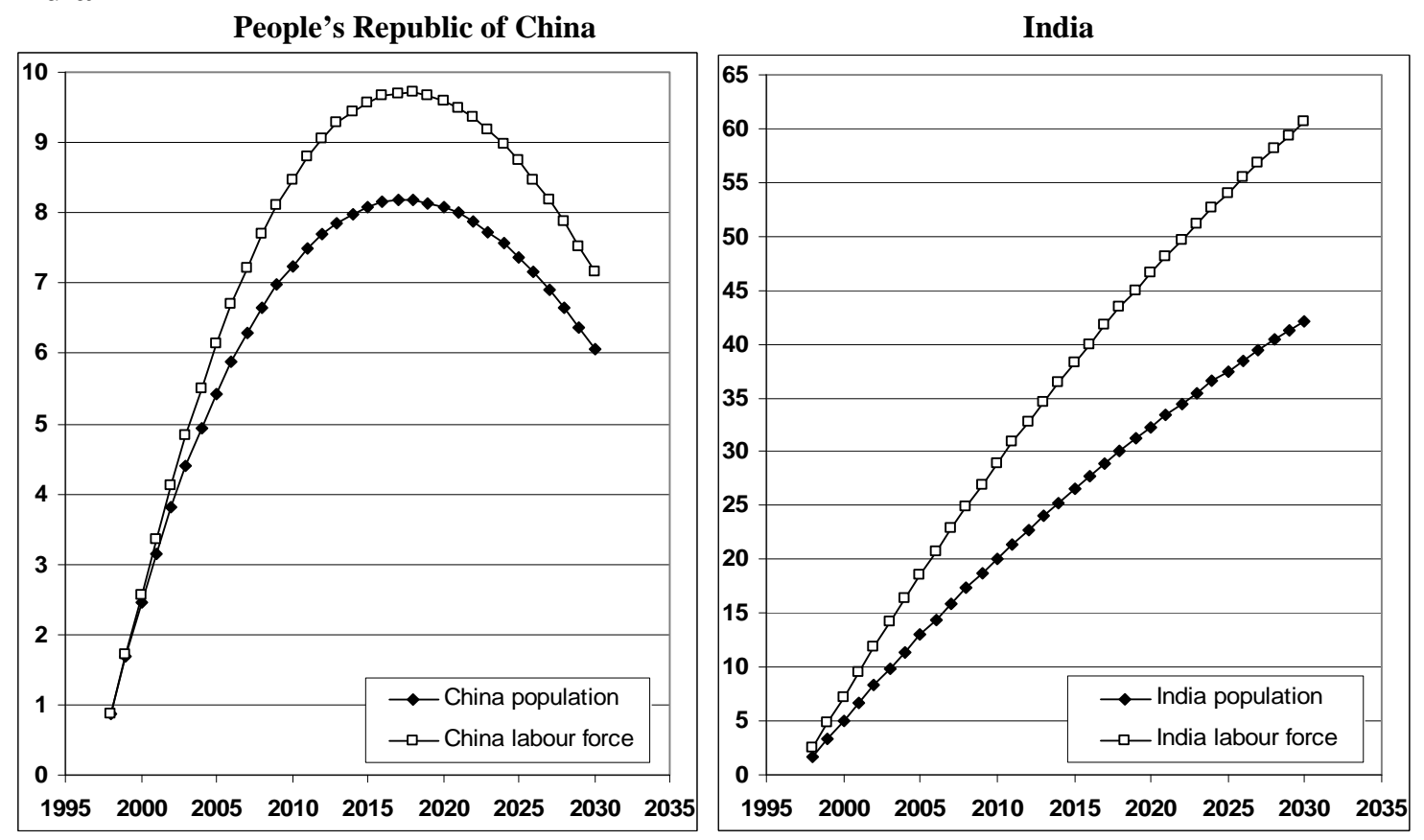

a These are cumulative \% departures from the base year 1997, drawn from the baseline simulation in which China's fertility is projected to decline faster than India's and in which India commences with a much younger population. 
Figure 5: Baseline Real GNP Per Capita Growth Rates ${ }^{a}$, \% a year

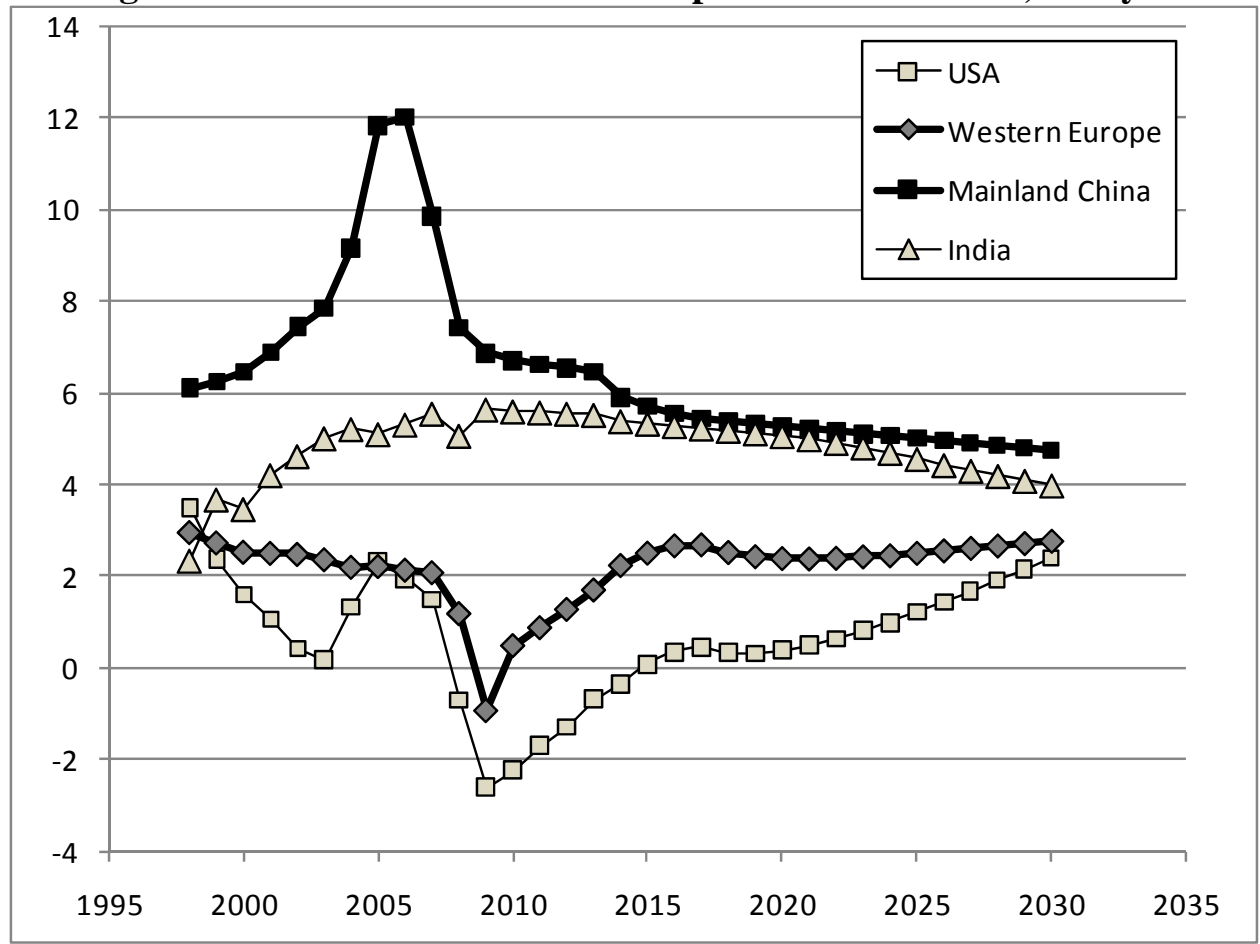

${ }^{\mathrm{a}}$ These are baseline annual growth rates of simulated real GNP per capita and so include net foreign income, which is substantial for China. They diverge in the later years for this reason and because China's population declines while India's continues to rise.

Figure 6: Baseline Demographic Dividends 2000 to 2030 (\% increase in real per capita income due to age distribution change)

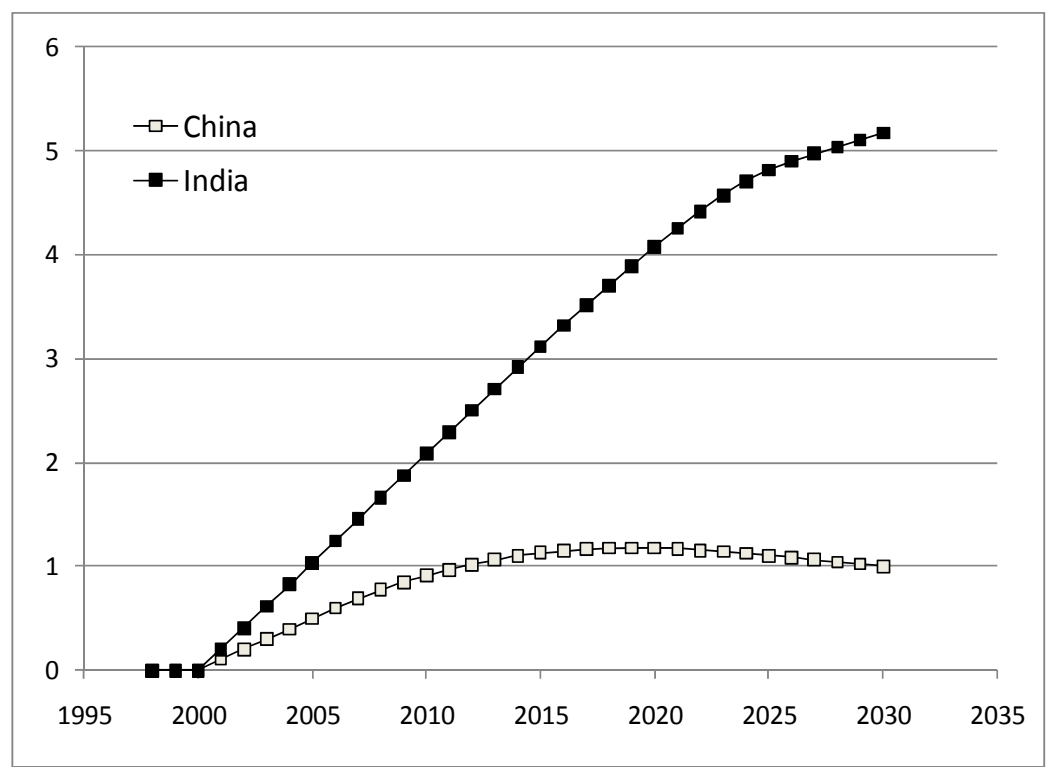

${ }^{a}$ For the case of China, this compares a simulation under baseline conditions that retains a constant age distribution, but all population groups following the baseline total population growth path, with the full baseline in which all age distributions are fully endogenous. A separate but corresponding "constant age distribution” simulation is made for India and a similar comparison made. 
Figure 7: Population and Labor Force: Alternative Scenarios ${ }^{\text {a }}$

China: Two-Child Policy

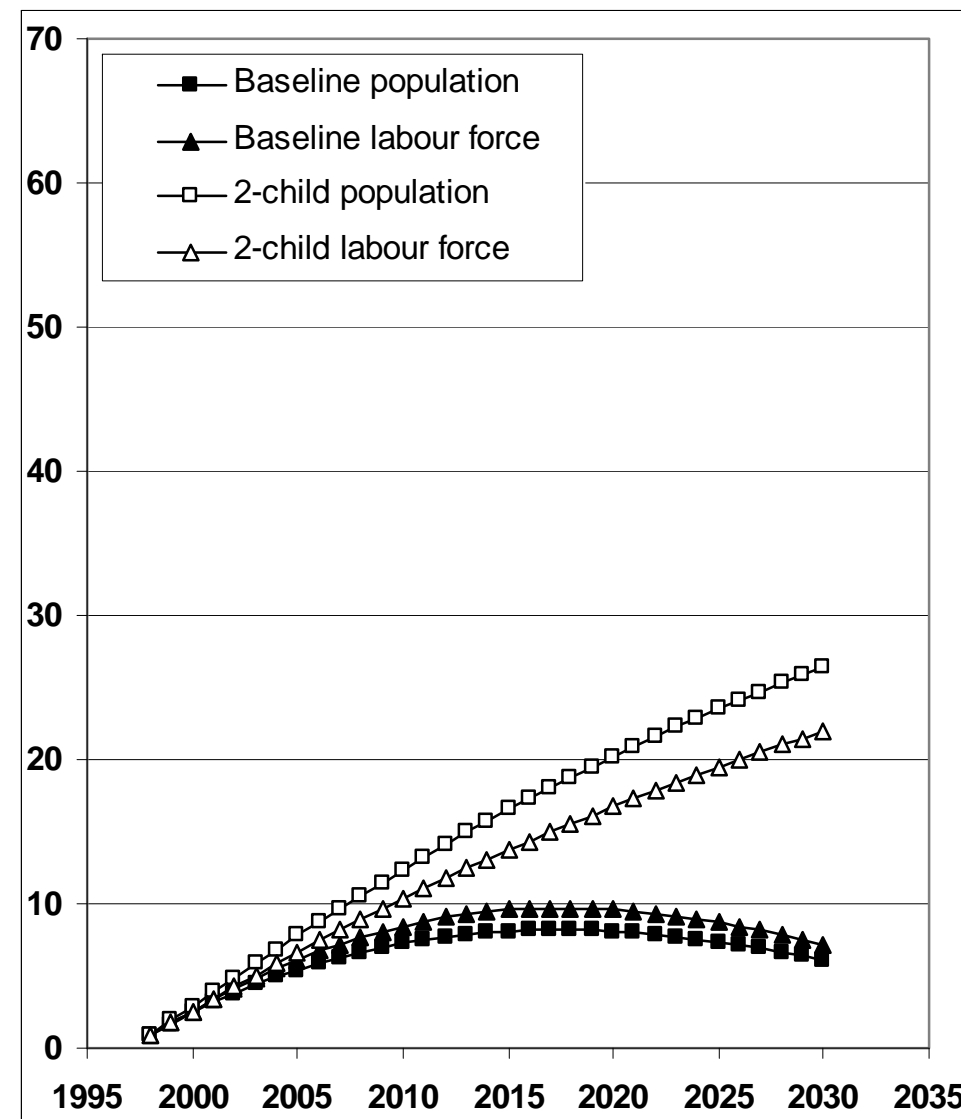

India: Lower fertility

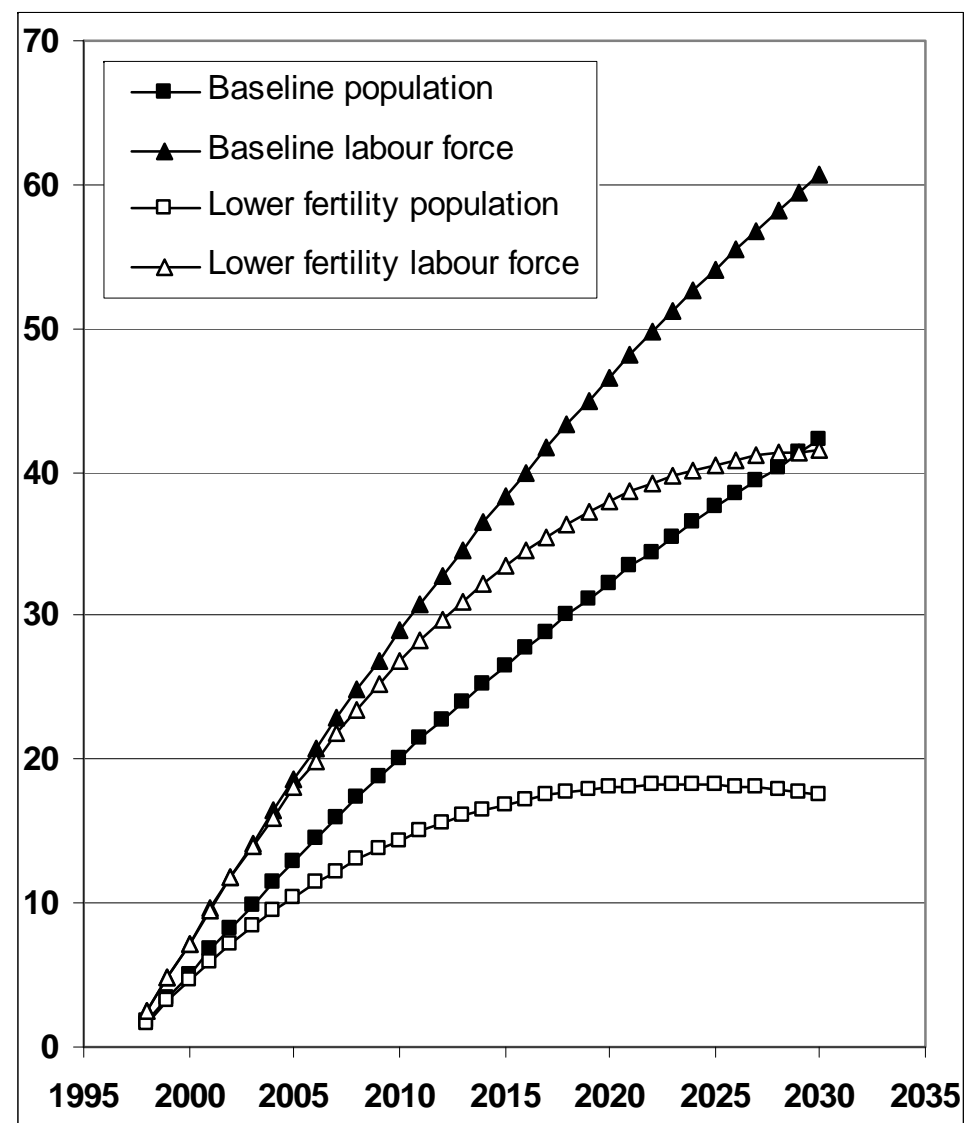

${ }^{\mathrm{a}}$ These are cumulative \% departures from the base year 1997. 
Figure 8: Projected Total, Youth, and Non-Working-Aged (60+) Dependency Ratios ${ }^{\text {a }}$

China: 2 Baseline and Two-Child Policy

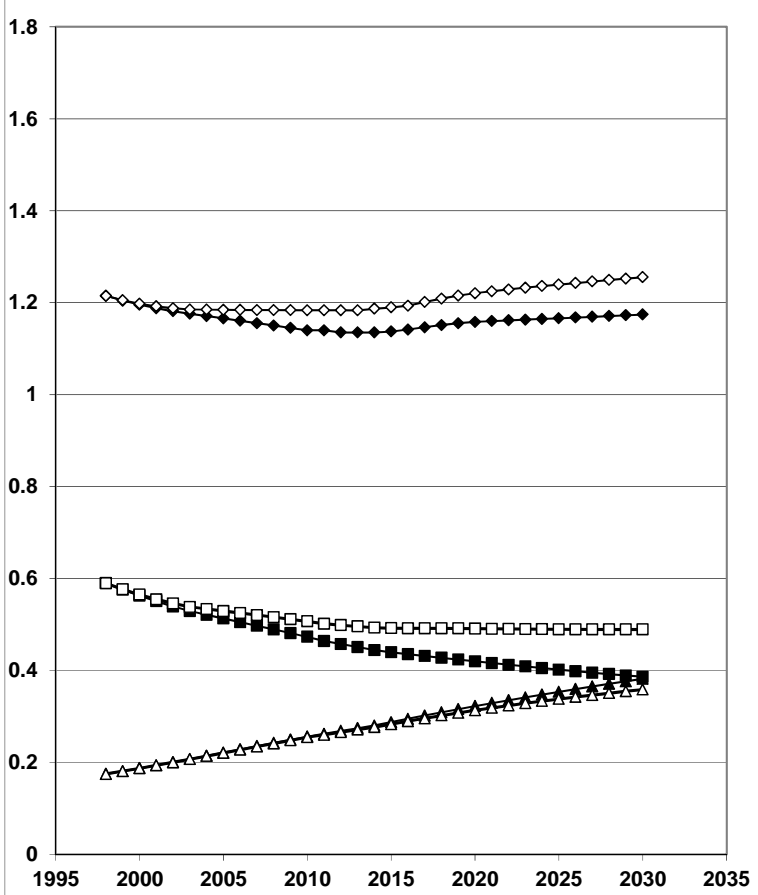

India: Baseline and Lower fertility

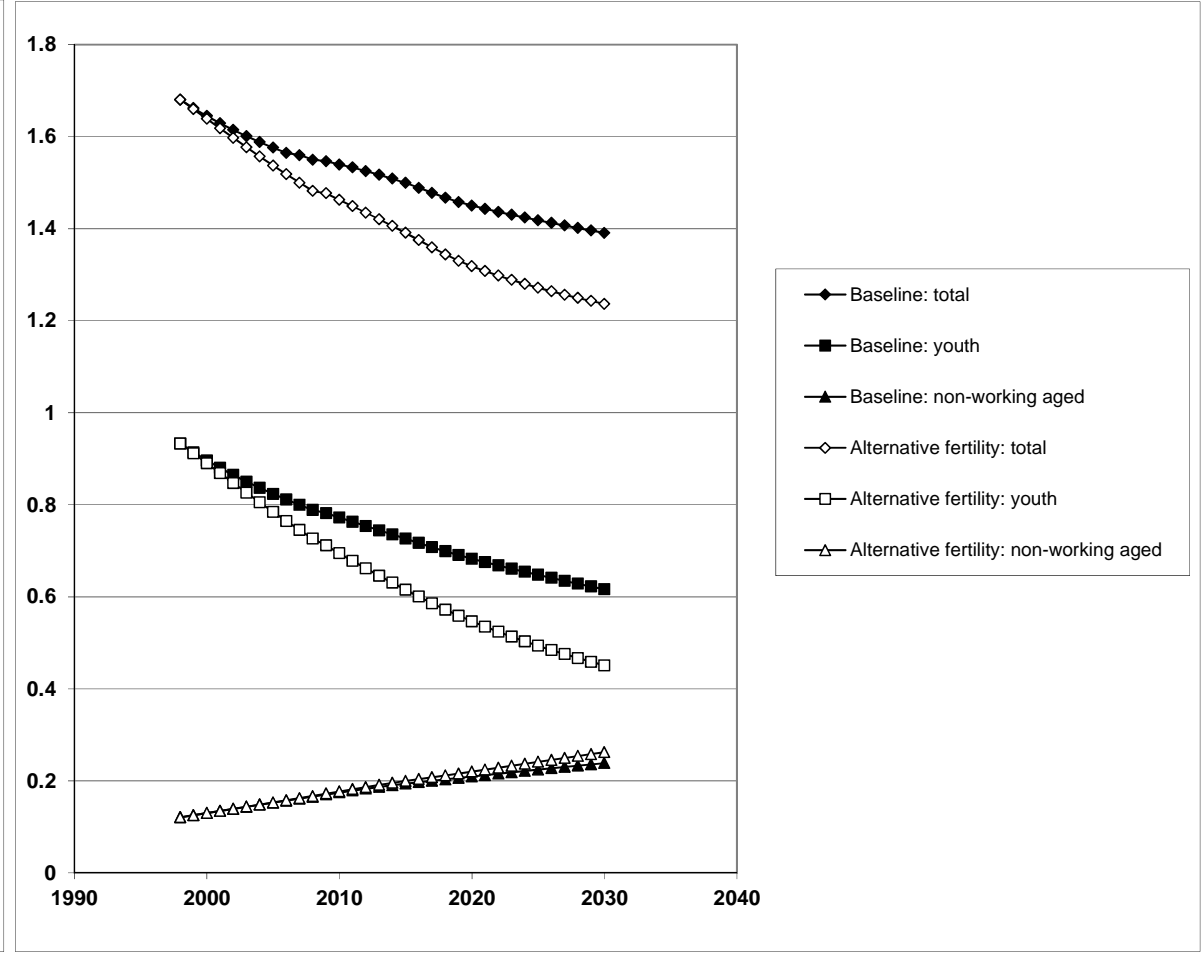

${ }^{\mathrm{a}}$ These are the simulated ratios of the total population, the total youth population $(0-15)$, and the non-working-aged population, to the full-time equivalent labor force. 
Figure 9: Projected Dividend Ratios for India and China ${ }^{\mathrm{a}}$

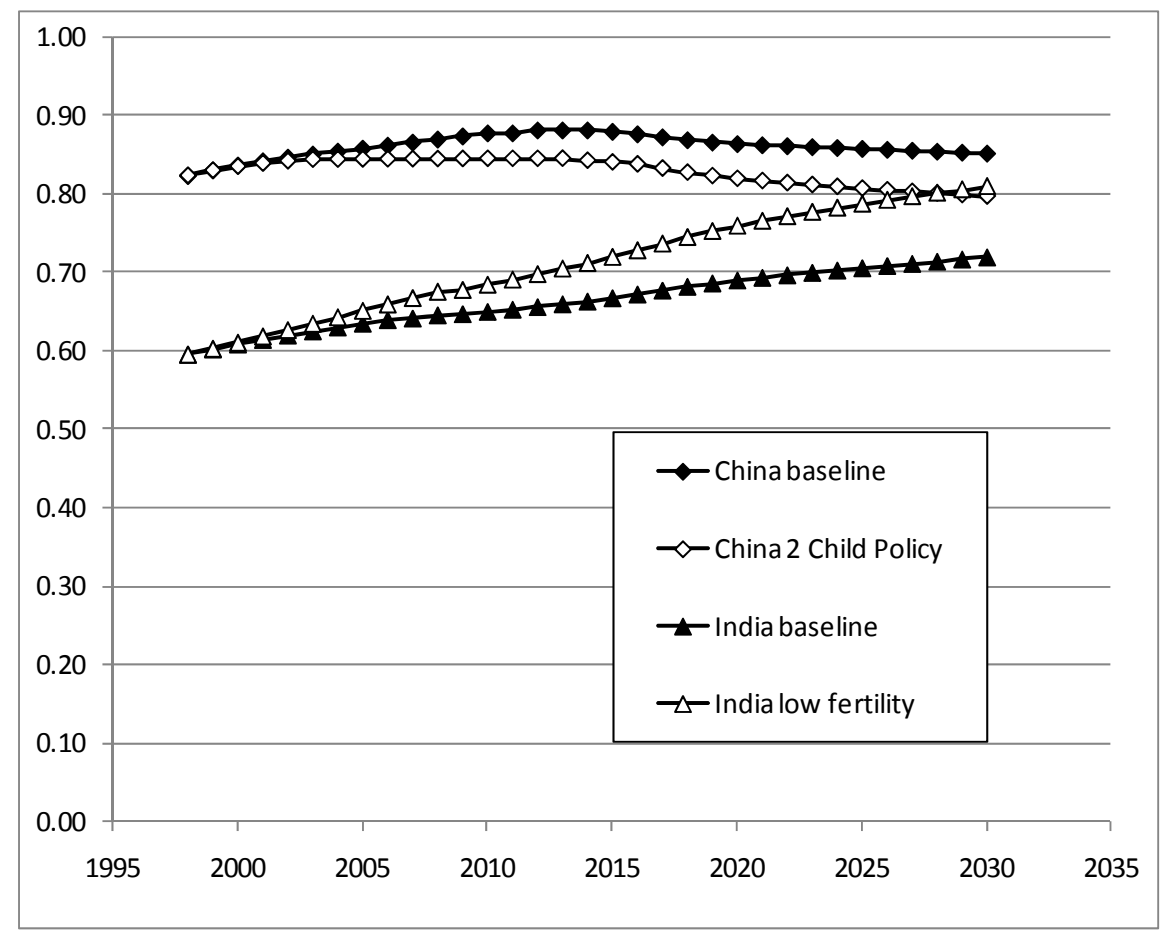

a These are simply the inverses of the total dependency ratios in Figure 8. They measure the number of workers for each dependent.

Figure 10: GDP, Real Wages and Real per Capita Income Alternative Scenarios (\% Departures from the Baseline) ${ }^{\mathrm{a}}$
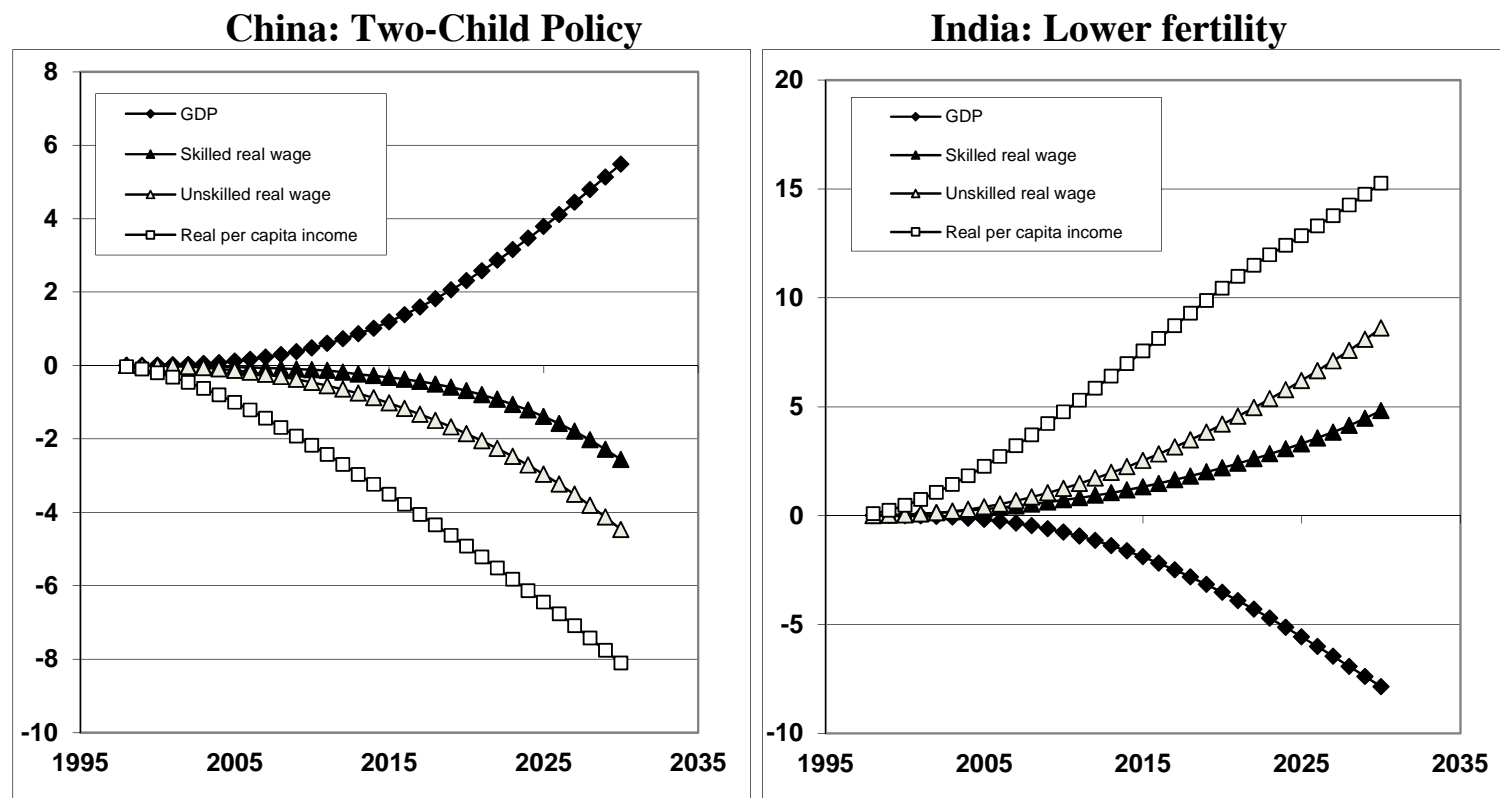

${ }^{\mathrm{a}}$ These are percentage departures from the baseline simulation for each year. 
Figure 11: Elasticities of GDP and Per Capita Income to Target Fertility Rate ${ }^{\mathrm{a}}$

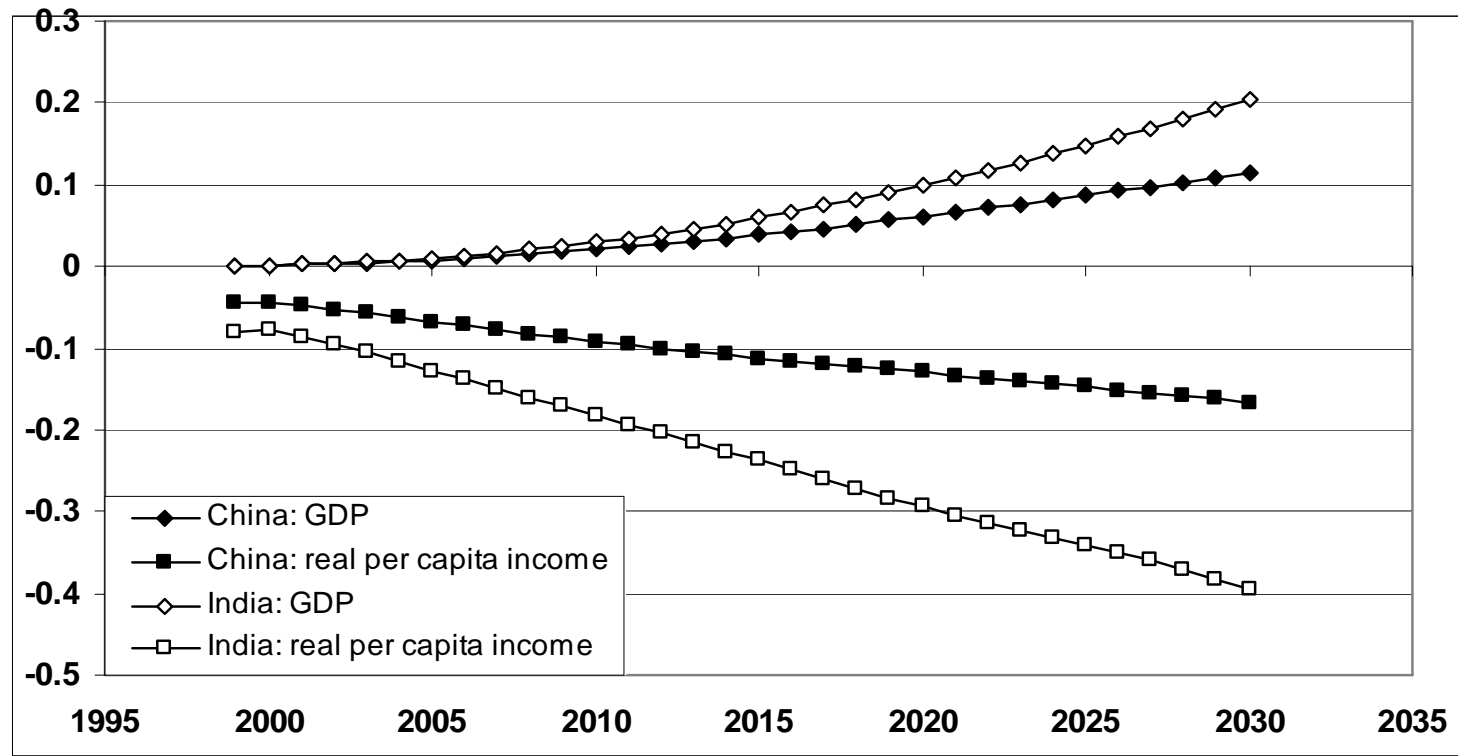

${ }^{\mathrm{a}}$ These are the percentage changes in real GDP and real per capita income for each corresponding percentage change in the target fertility rate. 
Table 1: Birth and Total Fertility Rates in China and India

\begin{tabular}{rcccc}
\hline & \multicolumn{3}{c}{ China } & \multicolumn{2}{c}{ India } \\
\hline & Birth rate $^{\mathrm{a}}$ & TFR $^{\mathrm{b}}$ & Birth rate & TFR \\
Base year, 1997 & 76 & 1.91 & 139 & 3.47 \\
2010 & 62 & 1.56 & 114 & 2.86 \\
2020 & 59 & 1.47 & 106 & 2.65 \\
2030 & 58 & 1.44 & 102 & 2.56 \\
\hline
\end{tabular}

${ }^{\mathrm{a}}$ Birth rates are here defined as the number of births per year per thousand women of fertile age. They are modified to allow for the modeling simplification that the fertile age group spans 15-39.

b Total fertility rates (TFR) are the average number of children borne by a woman throughout her life.

Source: Aggregated from United Nations (2003), US Department of CommerceU.S. Bureau of the Census "International Data Base”, as compiled by Chan and Tyers (2006).

Table 2: Age-Gender Specific Participation Rates in China and India, Base Year (1997) and Projected, 2030

\begin{tabular}{lcccc}
\hline Full-time equivalent workers per person & \multicolumn{2}{c}{ PRC } & \multicolumn{2}{c}{ India } \\
\cline { 2 - 5 } & Males & Females & Males & Females \\
15-39 & & & & \\
Initial (1997) & 0.79 & 0.60 & 0.81 & 0.35 \\
2030 & 0.77 & 0.61 & 0.83 & 0.36 \\
40-59 & & & & \\
Initial (1997) & 0.91 & 0.43 & 0.95 & 0.38 \\
2030 & 0.93 & 0.45 & 0.96 & 0.40 \\
60+ & & & & \\
Initial (1997) & 0.24 & 0.04 & 0.55 & 0.14 \\
2030 & 0.27 & 0.08 & 0.55 & 0.15 \\
\hline
\end{tabular}

a Projections of these parameters to 2020 assume convergence on target rates observed in comparatively "advanced" countries. Only the end point values are shown here but the model uses values that change with time along the path to convergence. Note, also that these are averages over the skilled and unskilled categories. In the case of China participation by skilled (educated) women is much higher than for unskilled, particularly for 40+, contributing an extra per cent to the 2030 average.

Source: Values to 1997 are from United Nations (2000). For splits by skill level see Tyers and Bain (2006). 
Table 3. Dependency and Dividend Ratios (\%) ${ }^{\mathrm{a}}$

\begin{tabular}{lccc}
\hline & & China & India \\
\hline Youth / working & Initial & 59.0 & 93.3 \\
& 2030 & 38.5 & 61.6 \\
Non-working aged / working & Initial & 17.5 & 12.1 \\
\multirow{2}{*}{ Non-working of working age / working } & 2030 & 38.1 & 23.9 \\
& Initial & 45.0 & 62.7 \\
Total dependency ratio: non-working / working & 2030 & 40.4 & 53.6 \\
& Initial & 121.5 & 168.1 \\
Dividend ratio: inverse of total dependency & 2030 & 117.0 & 139.1 \\
& Initial & 82.3 & 59.5 \\
\hline
\end{tabular}

${ }^{\mathrm{a}}$ The dependency ratios may be read as the number of dependents per 100 full time equivalent workers, while the dividend ratios give the number of full time equivalent workers per dependent. The declines in non-working of working age dependency are due primarily to aging of the female labor force, though female skilling contributes in the case of China.

Source: The base period ratios are constructed from population statistics from United Nations (2005) and those for 2030 from simulation results described in the text.

Table 4: Baseline Population and Labor Force Structure in China and India

\begin{tabular}{|c|c|c|c|c|c|c|}
\hline & & China & & & India & \\
\hline Population & Millions & $\begin{array}{c}\% \\
\text { Female }\end{array}$ & $\% 60+$ & Millions & $\begin{array}{c}\% \% \\
\text { Female }\end{array}$ & $\% 60+$ \\
\hline Initial (1997) & 1272 & 48.5 & 9.7 & 955 & 48.2 & 6.9 \\
\hline 2010 & 1364 & 48.7 & 14.8 & 1146 & 48.4 & 10.6 \\
\hline 2020 & 1375 & 48.8 & 18.4 & 1263 & 48.5 & 13.0 \\
\hline 2030 & 1353 & 49.0 & 21.2 & 1349 & 48.5 & 14.8 \\
\hline Labor Force & & & $\% 40+$ & & & $\% 40+$ \\
\hline Initial (1997) & 570 & 37.2 & 33.9 & 356 & 27.4 & 36.3 \\
\hline 2010 & 618 & 36.7 & 41.2 & 459 & 27.1 & 41.7 \\
\hline 2020 & 624 & 36.4 & 45.4 & 522 & 27.2 & 45.1 \\
\hline 2030 & 613 & 36.1 & 48.2 & 568 & 27.5 & 47.9 \\
\hline
\end{tabular}

Source: Projection using the baseline simulation of the model described in the text. The labor forces are measured in full-time equivalent workers. 
Table 5: Economic Effects of Alternative Fertility Scenarios

\begin{tabular}{cccccccc}
\hline & $\begin{array}{c}\text { Real } \\
\text { capital } \\
\text { stock }\end{array}$ & $\begin{array}{c}\text { Labor } \\
\text { force }\end{array}$ & $\begin{array}{c}\text { Real } \\
\text { skilled } \\
\text { wage }\end{array}$ & $\begin{array}{c}\text { Real } \\
\text { production } \\
\text { wage }\end{array}$ & $\begin{array}{c}\text { Terms of } \\
\text { trade }\end{array}$ & $\begin{array}{c}\text { Real } \\
\text { GDP }\end{array}$ & $\begin{array}{c}\text { Real } \\
\text { GNP per } \\
\text { capita }\end{array}$ \\
\hline \multicolumn{7}{c}{ China: Two-Child Policy - \% Departures from the baseline } \\
2010 & 1.5 & 1.1 & -0.1 & -0.5 & -0.0 & 0.3 & -2.3 \\
2020 & 3.0 & 6.5 & -0.7 & -1.9 & -0.4 & 1.9 & -4.9 \\
2030 & 3.6 & 13.6 & -2.6 & -4.5 & -1.2 & 5.8 & -8.1 \\
\hline
\end{tabular}

India: Low Fertility Projections - \% Departures from the baseline

\begin{tabular}{llllllll}
\hline 2010 & -0.3 & -1.7 & 0.7 & 1.3 & 0.1 & -2.2 & 4.8 \\
2020 & -2.0 & -6.3 & 2.2 & 4.2 & 0.9 & -3.5 & 10.4 \\
2030 & -5.2 & -12.7 & 4.8 & 8.6 & 2.5 & -7.9 & 15.3 \\
\hline
\end{tabular}

Source: The baseline, China 2-Child Policy and India Low Fertility projections from the model described in the text. 
ECONOMICS DISCUSSION PAPERS

2009

\begin{tabular}{|c|c|c|}
\hline $\begin{array}{l}\text { DP } \\
\text { NUMBER }\end{array}$ & AUTHORS & TITLE \\
\hline 09.01 & Le, A.T. & $\begin{array}{l}\text { ENTRY INTO UNIVERSITY: ARE THE CHILDREN OF } \\
\text { IMMIGRANTS DISADVANTAGED? }\end{array}$ \\
\hline 09.02 & $\mathrm{Wu}, \mathrm{Y}$. & $\begin{array}{l}\text { CHINA'S CAPITAL STOCK SERIES BY REGION AND } \\
\text { SECTOR }\end{array}$ \\
\hline 09.03 & Chen, M.H. & $\begin{array}{l}\text { UNDERSTANDING WORLD COMMODITY PRICES } \\
\text { RETURNS, VOLATILITY AND DIVERSIFACATION }\end{array}$ \\
\hline 09.04 & Velagic, R. & UWA DISCUSSION PAPERS IN ECONOMICS: THE FIRST 650 \\
\hline 09.05 & McLure, M. & $\begin{array}{l}\text { ROYALTIES FOR REGIONS: ACCOUNTABILITY AND } \\
\text { SUSTAINABILITY }\end{array}$ \\
\hline 09.06 & Chen, A. and Groenewold, N. & $\begin{array}{l}\text { REDUCING REGIONAL DISPARITIES IN CHINA: AN } \\
\text { EVALUATION OF ALTERNATIVE POLICIES }\end{array}$ \\
\hline 09.07 & $\begin{array}{l}\text { Groenewold, N. and Hagger, } \\
\text { A. }\end{array}$ & $\begin{array}{l}\text { THE REGIONAL ECONOMIC EFFECTS OF IMMIGRATION: } \\
\text { SIMULATION RESULTS FROM A SMALL CGE MODEL. }\end{array}$ \\
\hline 09.08 & Clements, K. and Chen, D. & $\begin{array}{l}\text { AFFLUENCE AND FOOD: SIMPLE WAY TO INFER } \\
\text { INCOMES }\end{array}$ \\
\hline 09.09 & Clements, K. and Maesepp, M. & A SELF-REFLECTIVE INVERSE DEMAND SYSTEM \\
\hline 09.10 & Jones, C. & $\begin{array}{l}\text { MEASURING WESTERN AUSTRALIAN HOUSE PRICES: } \\
\text { METHODS AND IMPLICATIONS }\end{array}$ \\
\hline 09.11 & Siddique, M.A.B. & $\begin{array}{l}\text { WESTERN AUSTRALIA-JAPAN MINING CO-OPERATION: } \\
\text { AN HISTORICAL OVERVIEW }\end{array}$ \\
\hline 09.12 & Weber, E.J. & $\begin{array}{l}\text { PRE-INDUSTRIAL BIMETALLISM: THE INDEX COIN } \\
\text { HYPTHESIS }\end{array}$ \\
\hline 09.13 & McLure, M. & $\begin{array}{l}\text { PARETO AND PIGOU ON OPHELIMITY, UTILITY AND } \\
\text { WELFARE: IMPLICATIONS FOR PUBLIC FINANCE }\end{array}$ \\
\hline 09.14 & Weber, E.J. & $\begin{array}{l}\text { WILFRED EDWARD GRAHAM SALTER: THE MERITS OF A } \\
\text { CLASSICAL ECONOMIC EDUCATION }\end{array}$ \\
\hline 09.15 & Tyers, R. and Huang, L. & $\begin{array}{l}\text { COMBATING CHINA'S EXPORT CONTRACTION: FISCAL } \\
\text { EXPANSION OR ACCELERATED INDUSTRIAL REFORM }\end{array}$ \\
\hline 09.16 & $\begin{array}{l}\text { Zweifel, P., Plaff, D. and } \\
\text { Kühn, J. }\end{array}$ & $\begin{array}{l}\text { IS REGULATING THE SOLVENCY OF BANKS COUNTER- } \\
\text { PRODUCTIVE? }\end{array}$ \\
\hline 09.17 & Clements, K. & THE PHD CONFERENCE REACHES ADULTHOOD \\
\hline 09.18 & McLure, M. & $\begin{array}{l}\text { THIRTY YEARS OF ECONOMICS: UWA AND THE WA } \\
\text { BRANCH OF THE ECONOMIC SOCIETY FROM } 1963 \text { TO } 1992\end{array}$ \\
\hline 09.19 & Harris, R.G. and Robertson, P. & $\begin{array}{l}\text { TRADE, WAGES AND SKILL ACCUMULATION IN THE } \\
\text { EMERGING GIANTS }\end{array}$ \\
\hline 09.20 & $\begin{array}{l}\text { Peng, J., Cui, J., Qin, F. and } \\
\text { Groenewold, N. }\end{array}$ & STOCK PRICES AND THE MACRO ECONOMY IN CHINA \\
\hline 09.21 & Chen, A. and Groenewold, N. & $\begin{array}{l}\text { REGIONAL EQUALITY AND NATIONAL DEVELOPMENT IN } \\
\text { CHINA: IS THERE A TRADE-OFF? }\end{array}$ \\
\hline
\end{tabular}




\begin{tabular}{|c|c|c|}
\hline \multicolumn{3}{|c|}{$\begin{array}{l}\text { ECONOMICS DISCUSSION PAPERS } \\
2010\end{array}$} \\
\hline $\begin{array}{l}\text { DP } \\
\text { NUMBER }\end{array}$ & AUTHORS & TITLE \\
\hline 10.01 & Hendry, D.F. & $\begin{array}{l}\text { RESEARCH AND THE ACADEMIC: A TALE OF } \\
\text { TWO CULTURES }\end{array}$ \\
\hline 10.02 & $\begin{array}{l}\text { McLure, M., Turkington, D. and Weber, } \\
\text { E.J. }\end{array}$ & A CONVERSATION WITH ARNOLD ZELLNER \\
\hline 10.03 & $\begin{array}{l}\text { Butler, D.J., Burbank, V.K. and } \\
\text { Chisholm, J.S. }\end{array}$ & $\begin{array}{l}\text { THE FRAMES BEHIND THE GAMES: PLAYER'S } \\
\text { PERCEPTIONS OF PRISONER'S DILEMMA, } \\
\text { CHICKEN, DICTATOR, AND ULTIMATUM } \\
\text { GAMES }\end{array}$ \\
\hline 10.04 & Harris, R.G., Robertson, P.E. and Xu, J.Y. & $\begin{array}{l}\text { THE INTERNATIONAL EFFECTS OF CHINA'S } \\
\text { GROWTH, TRADE AND EDUCATION BOOMS }\end{array}$ \\
\hline 10.05 & Clements, K.W., Mongey, S. and Si, J. & $\begin{array}{l}\text { THE DYNAMICS OF NEW RESOURCE PROJECTS } \\
\text { A PROGRESS REPORT }\end{array}$ \\
\hline 10.06 & Costello, G., Fraser, P. and Groenewold, N. & $\begin{array}{l}\text { HOUSE PRICES, NON-FUNDAMENTAL } \\
\text { COMPONENTS AND INTERSTATE SPILLOVERS: } \\
\text { THE AUSTRALIAN EXPERIENCE }\end{array}$ \\
\hline 10.07 & Clements, K. & $\begin{array}{l}\text { REPORT OF THE } 2009 \text { PHD CONFERENCE IN } \\
\text { ECONOMICS AND BUSINESS }\end{array}$ \\
\hline 10.08 & Robertson, P.E. & $\begin{array}{l}\text { INVESTMENT LED GROWTH IN INDIA: HINDU } \\
\text { FACT OR MYTHOLOGY? }\end{array}$ \\
\hline 10.09 & Fu, D., Wu, Y. and Tang, Y. & $\begin{array}{l}\text { THE EFFECTS OF OWNERSHIP STRUCTURE } \\
\text { AND INDUSTRY CHARACTERISTICS ON } \\
\text { EXPORT PERFORMANCE }\end{array}$ \\
\hline 10.10 & $\mathrm{Wu}, \mathrm{Y}$. & $\begin{array}{l}\text { INNOVATION AND ECONOMIC GROWTH IN } \\
\text { CHINA }\end{array}$ \\
\hline 10.11 & Stephens, B.J. & $\begin{array}{l}\text { THE DETERMINANTS OF LABOUR FORCE } \\
\text { STATUS AMONG INDIGENOUS AUSTRALIANS }\end{array}$ \\
\hline 10.12 & Davies, M. & $\begin{array}{l}\text { FINANCING THE BURRA BURRA MINES, } \\
\text { SOUTH AUSTRALIA: LIQUIDITY PROBLEMS } \\
\text { AND RESOLUTIONS }\end{array}$ \\
\hline 10.13 & Tyers, R. and Zhang, Y. & APPRECIATING THE RENMINBI \\
\hline 10.14 & Clements, K.W., Lan, Y. and Seah, S.P. & $\begin{array}{l}\text { THE BIG MAC INDEX TWO DECADES ON } \\
\text { AN EVALUATION OF BURGERNOMICS }\end{array}$ \\
\hline 10.15 & Robertson, P.E. and Xu, J.Y. & $\begin{array}{l}\text { IN CHINA'S WAKE: } \\
\text { HAS ASIA GAINED FROM CHINA'S GROWTH? }\end{array}$ \\
\hline 10.16 & Clements, K.W. and Izan, H.Y. & $\begin{array}{l}\text { THE PAY PARITY MATRIX: A TOOL FOR } \\
\text { ANALYSING THE STRUCTURE OF PAY }\end{array}$ \\
\hline 10.17 & Gao, G. & WORLD FOOD DEMAND \\
\hline 10.18 & Wu, Y. & $\begin{array}{l}\text { INDIGENOUS INNOVATION IN CHINA: } \\
\text { IMPLICATIONS FOR SUSTAINABLE GROWTH }\end{array}$ \\
\hline 10.19 & Robertson, P.E. & DECIPHERING THE HINDU GROWTH EPIC \\
\hline 10.20 & Stevens, G. & $\begin{array}{l}\text { RESERVE BANK OF AUSTRALIA-THE ROLE OF } \\
\text { FINANCE }\end{array}$ \\
\hline
\end{tabular}




\begin{tabular}{|l|l|l|}
\hline 10.21 & Widmer, P.K., Zweifel, P. and Farsi, M. & $\begin{array}{l}\text { ACCOUNTING FOR HETEROGENEITY IN THE } \\
\text { MEASUREMENT OF HOSPITAL PERFORMANCE }\end{array}$ \\
\hline 10.22 & McLure, M. & $\begin{array}{l}\text { ASSESSMENTS OF A. C. PIGOU'S FELLOWSHIP } \\
\text { THESES }\end{array}$ \\
\hline 10.23 & Poon, A.R. & $\begin{array}{l}\text { THE ECONOMICS OF NONLINEAR PRICING: } \\
\text { EVIDENCE FROM AIRFARES AND GROCERY } \\
\text { PRICES }\end{array}$ \\
\hline 10.24 & Halperin, D. & $\begin{array}{l}\text { FORECASTING METALS RETURNS: A } \\
\text { BAYESIAN DECISION THEORETIC APPROACH }\end{array}$ \\
\hline 10.25 & Clements, K.W. and Si. J. & $\begin{array}{l}\text { THE INVESTMENT PROJECT PIPELINE: COST } \\
\text { ESCALATION, LEAD-TIME, SUCCESS, FAILURE } \\
\text { AND SPEED }\end{array}$ \\
\hline 10.26 & Chen, A., Groenewold, N. and Hagger, A.J. & $\begin{array}{l}\text { THE REGIONAL ECONOMIC EFFECTS OF A } \\
\text { REDUCTION IN CARBON EMISSIONS }\end{array}$ \\
\hline 10.27 & $\begin{array}{l}\text { Siddique, A., Selvanathan, E.A. and } \\
\text { Selvanathan, S. }\end{array}$ & $\begin{array}{l}\text { REMITTANCES AND ECONOMIC GROWTH: } \\
\text { EMPIRICAL EVIDENCE FROM BANGLADESH, } \\
\text { INDIA AND SRI LANKA }\end{array}$ \\
\hline
\end{tabular}




\begin{tabular}{|c|c|c|}
\hline \multicolumn{3}{|c|}{$\begin{array}{l}\text { ECONOMICS DISCUSSION PAPERS } \\
2011\end{array}$} \\
\hline $\begin{array}{l}\text { DP } \\
\text { NUMBER }\end{array}$ & AUTHORS & TITLE \\
\hline 11.01 & Robertson, P.E. & $\begin{array}{l}\text { DEEP IMPACT: CHINA AND THE WORLD } \\
\text { ECONOMY }\end{array}$ \\
\hline 11.02 & Kang, C. and Lee, S.H. & $\begin{array}{l}\text { BEING KNOWLEDGEABLE OR SOCIABLE? } \\
\text { DIFFERENCES IN RELATIVE IMPORTANCE OF } \\
\text { COGNITIVE AND NON-COGNITIVE SKILLS }\end{array}$ \\
\hline 11.03 & Turkington, D. & DIFFERENT CONCEPTS OF MATRIX CALCULUS \\
\hline 11.04 & Golley, J. and Tyers, R. & $\begin{array}{l}\text { CONTRASTING GIANTS: DEMOGRAPHIC CHANGE } \\
\text { AND ECONOMIC PERFORMANCE IN CHINA AND } \\
\text { INDIA }\end{array}$ \\
\hline 11.05 & Collins, J., Baer, B. and Weber, E.J. & $\begin{array}{l}\text { ECONOMIC GROWTH AND EVOLUTION: } \\
\text { PARENTAL PREFERENCE FOR QUALITY AND } \\
\text { QUANTITY OF OFFSPRING }\end{array}$ \\
\hline 11.06 & Turkington, D. & $\begin{array}{l}\text { ON THE DIFFERENTIATION OF THE LOG } \\
\text { LIKELIHOOD FUNCTION USING MATRIX } \\
\text { CALCULUS }\end{array}$ \\
\hline 11.07 & Groenewold, N. and Paterson, J.E.H. & $\begin{array}{l}\text { STOCK PRICES AND EXCHANGE RATES IN } \\
\text { AUSTRALIA: ARE COMMODITY PRICES THE } \\
\text { MISSING LINK? }\end{array}$ \\
\hline 11.08 & Chen, A. and Groenewold, N. & $\begin{array}{l}\text { REDUCING REGIONAL DISPARITIES IN CHINA: IS } \\
\text { INVESTMENT ALLOCATION POLICY EFFECTIVE? }\end{array}$ \\
\hline 11.09 & Williams, A., Birch, E. and Hancock, P. & $\begin{array}{l}\text { THE IMPACT OF ON-LINE LECTURE RECORDINGS } \\
\text { ON STUDENT PERFORMANCE }\end{array}$ \\
\hline 11.10 & Pawley, J. and Weber, E.J. & $\begin{array}{l}\text { INVESTMENT AND TECHNICAL PROGRESS IN THE } \\
\text { G7 COUNTRIES AND AUSTRALIA }\end{array}$ \\
\hline
\end{tabular}

